\title{
CLEARING A PATH TOWARDS EFFECTIVE ALIEN INVASIVE CONTROL: THE LEGAL CONUNDRUM
}

\author{
AR Paterson* \\ "Bioinvasion is a deeply unsatisfying topic. It is messy, frustrating, \\ depressing, and unpredictable: it does not lend itself to neat solution."
}

\section{Introduction}

Alien invasive plants (AIPs) pose significant ecological, social and economic challenges for South Africa. These species threaten South Africa's rich biodiversity, deplete our scarce water resources, reduce the agricultural potential of land, cause soil erosion and intensify flooding and fires. According to recent estimations, over eight percent of land in South Africa has been invaded by AIPs ${ }^{2}$ and at current rates of expansion their impact could double in the next fifteen years. ${ }^{3}$

The significance of the threat posed by AIPs is recognised in a number of international ${ }^{4}$ and regional conventions. ${ }^{5}$ The South African government has

* BSocSci LLB (Cape Town) LLM Environmental Law (Cape Town). Senior Lecturer, Institute of Marine and Environmental Law, Faculty of Law, University of Cape Town. The article was last updated on 30 January 2006.

1 Bright Life Out of Bounds 2.

2 DEAT Environmental Impacts of Invading Alien Plants in South Africa 2.

3 Wynberg 2002 South African Journal of Science 236-237.

4 See the Convention on Biological Diversity which provides that each contracting party must prevent the introduction of, control or eradicate those alien species which threaten ecosystems, habitats or species (a $8(\mathrm{~h})$ ). This provision is detailed in the Guiding Principles for the Implementation of Article 8(h) (Decision VI/23) which urge state parties to, amongst other things: create mechanisms to co-ordinate national programmes; review relevant policies, legislation institutions to identify gaps, inconsistencies and conflicts, and adjust or develop policies, legislation and institutions as appropriate; and enhance cooperation between various sectors (par 10(b)-(d)). See further the resolution on Invasive 
similarly identified the removal of AIPs as a priority ${ }^{6}$ and has established a range of programmes to deal with the crises including the Working for Water programme $^{7}$ the Ukuvuka Campaign ${ }^{8}$ and most recently the Working on Fire programme. ${ }^{9}$ As of January 2004, government expenditure on the Working for Water programme alone amounted to R3.2 billion ${ }^{10}$ and it is estimated that it will cost R650 million per year for the next twenty years to bring AIPs under control. ${ }^{11}$

Species and Wetlands (Resolution VII/14) under the Convention on Wetlands of International Importance especially as Waterfowl Habitat.

5 See the Revised SADC Protocol on Shared Watercourse Systems which imposes an obligation on state parties to "...where appropriate, jointly, protect, preserve and manage ecosystems of shared water resources" a range of measures including "...preventing (the) introduction of alien and new species" (a 4(2)(c)). See also the Revised African Convention on the Conservation of Nature and Natural Resources which states that parties shall "...strictly control the international and, in so far as possible, accidental introduction, in any area, of species which are not native to that area, including modified organisms, and endeavour to eradicate those already introduced where the consequences are detrimental to native species or to the environment in general" (a IX(2)(h)). See finally the Protocol Concerning Protected Areas and Wild Fauna and Flora in the Eastern African Region (a 7).

6 See DEAT White Paper on the Conservation and Use of South Africa's Biodiversity (hereafter: White Paper on Biodiversity). One of the key policy objectives of the White Paper is to prevent the introduction of potentially harmful alien species and control and eradicate alien species which threaten ecosystems, habitats or species (Policy Objective $1.6,36-38)$.

7 The Working for Water programme commenced in 1995 to tackle the problem of AIPs and unemployment. It is a multi-departmental initiative led by the Department of Water Affairs and Forestry (DWAF), Department Environmental Affairs and Tourism (DEAT) and the Department of Agriculture. It currently operates approximately 300 projects throughout the country and aims to enhance water security, improve ecological integrity, restore the productive potential of land, promote sustainable use of natural resources and invest in the underprivileged sectors of society. For further information on the programme see http://www.dwaf.gov.za/wfw/.

8 The Ukuvuka Campaign was a four-year campaign initiated by the Working for Water programme and various corporate sponsors following the January 2000 fires that ravaged the Cape Peninsula. The campaign's aims included: to secure control over invading alien plants along the Table Mountain chain; assist in the rehabilitation process; create employment opportunities, training and poverty relief undertaken in accordance with the norms of the Working for Water programme; promote social cohesion through collaborative community efforts and breaking down social barriers; assist in establishing and implementing a fire-management plan of operation; and to build capacity to react when fires do occur. It was funded by corporate sponsors and government institutions. For more information on the Campaign see http://www.ukuvuka.org.za.

9 The Working on Fire programme, launched in 2002, is an R35m government funded programme aimed at: promoting an integrated approach to fire management; job creation; skills development; poverty relief; and establishing a national co-ordinated system for fire management. For more information see http://www.fire.uni-freiburg.de/WoF/.

10 Turpie 2004 South African Journal of Science 87.

11 La Maitre et al 2002 Forest Ecology and Management 143. 
The government has enacted eleven national and various provincial laws which contain mechanisms for regulating the different threats posed by AIPs. ${ }^{12}$ Certain of these laws are framework in nature while the majority are sectoral and aimed at regulating AIPs for one of the following four main purposes: biodiversity conservation; water conservation; agricultural management; and fire risk management. The responsibility for administering these laws spans four national departments, nine provincial environmental authorities, provincial conservation authorities, numerous local and statutory authorities. This fragmented regime, coupled with the adoption of a "command and control approach"13 to regulation, has proven inept in effectively regulating the spread of AIPs in South Africa. This reality led the previous Minister of Environmental Affairs and Tourism, Mr Valli Moosa, to call for the development of

.... coherent legislative framework ... streamlined along the lines of the principles endorsed by the Convention on Biological Diversity. ${ }^{14}$

This article critically analyses the government's attempts to develop such a "coherent legislative framework" to regulate AIPs in light of recent reform. ${ }^{15}$ It is divided into two parts. Part one critically considers South Africa's laws of relevance to AIPs and the current fragmented approach to planning and implementation. Part two provides some ideas regarding how the current legislative framework can be rationalised to entrench a more integrated, and

12 These laws include: the National Environmental Management Act 107 of 1998 (NEMA); National Environmental Management: Biodiversity Act 10 of 2004 (Biodiversity Act); National Environmental Management: Protected Areas Act 57 of 2003 (Protected Areas Act); Conservation of Agricultural Resources Act 43 of 1983 (CARA) - including the regulations published in GN R1048 Government Gazette 9238 of 25 May 1984, as amended; National Water Act 36 of 1998 (NWA); Mountain Catchment Areas Act 63 of 1970 (MCAA); National Veld and Forest Fire Act 101 of 1998 (NV\&FFA); Agricultural Pests Act 35 of 1983; Plant Improvement Act 53 of 1976; and various provincial nature conservation Ordinances and Acts.

13 In terms of this approach a government seeks to regulate human behaviour by prescribing a list of activities which people may or may not undertake. These activities are listed in laws. A failure to comply with these laws will lead to the person being penalised for the contravention.

14 Moosa "Invasive Aliens/Aquatic Invaders" 8.

15 This recent legislative reform includes: the commencement of the Biodiversity Act, Protected Areas Act and Local Government: Municipal Property Rates Act 6 of 2004 (Property Rates Act); the Sustainable Use of Agricultural Resources Draft Bill currently being drafted by the Department of Agriculture; and the Alien Invasive Regulations currently being drafted by DEAT under s 97 of the Biodiversity Act. 
hopefully more successful, approach to the future regulation of AIPs in South Africa.

\section{A critical analysis of the current legislative framework}

Critically analysing the strengths and weaknesses of the existing legislative framework is a key prerequisite for developing a new "coherent legislative framework". A failure to do so may simply result in any legislative reform repeating, and potentially exacerbating, existing problems rather than resolving them. This is no where more pertinent than in the context of AIP regulation in South Africa given the prolific array of relevant laws and authorities involved in administration and enforcement. The first part of the article therefore seeks critically to analyse the current legislative framework of relevance to AIP regulation in South Africa. It is divided into the following four broad sectors which echo the four main purposes highlighted above, namely: biodiversity conservation; water conservation; agricultural management; and fire risk management legislation. This is, however, preceded by considering South Africa's framework legislation of relevance to all four of these sectors.

\subsection{Framework legislation}

\subsubsection{National Environmental Management Act}

The National Environmental Management Act (NEMA) is South Africa's main framework environmental law that seeks to prescribe an integrated environmental management framework for the country. NEMA has two broad purposes, both of which are of relevance to the regulation of AIPs. Firstly, it purports to give effect to the overarching principles of co-operative governance

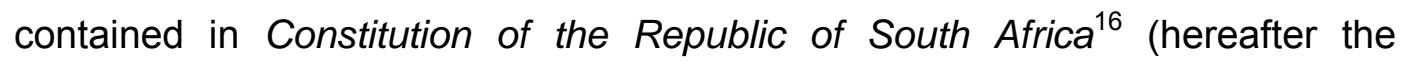
Constitution) and co-ordinates the functions of the myriad authorities whose 
activities may impact on the "environment". ${ }^{17}$ Secondly, it aims to fulfil the government's constitutional imperative under section 24(b) of the Constitution to take "reasonable legislative and other measures" to protect the environment.

Co-operative environmental governance is crucial within the sphere of AIP regulation given that there are numerous laws of relevance to their regulation which are administered by many different authorities. ${ }^{18}$ NEMA provides three main tools to foster co-operative environmental governance. Firstly, it prescribes a range of National Environmental Management Principles that must be taken into account by any organ of state whose actions "may significantly affect the environment". ${ }^{19}$ Many of these principles are of relevance to the regulation of AIPs and should inform the actions of all organs of state. ${ }^{20}$ Secondly, NEMA provides for the establishment of institutions to facilitate horizontal co-ordination between different national government departments and vertical co-ordination between national, provincial and local government authorities. These include the National Environmental Advisory Forum ${ }^{21}$ and the Committee for Environmental Co-ordination. ${ }^{22}$ Thirdly, it requires various

17 "Environment" is exceptionally broadly defined as "...the surroundings within which humans exist and that are made up of - (i) the land, water and atmosphere of the earth; micro-organisms, plant and animal life; any part or combination of (i) and (ii) and the interrelationships among and between them; and (iv) the physical, chemical, aesthetic and cultural properties and conditions of the foregoing that influence human health and wellbeing" (s 1).

18 See $\mathrm{n} 12$.

19 S 2. NEMA lists examples of circumstances in which these principles apply such as: guiding the formulation of environmental management and implementation plans; serving as guidelines by reference to which organs of state must exercise any function under NEMA or other statutory provisions concerning the protection of the environment; and guiding the interpretation, administration and implementation of NEMA and any other law concerned with the protection or management of the environment (s 2(1)).

20 These include: the disturbance of ecosystems and loss of biodiversity must be avoided, minimised and remedied (s 2(4)(a)(i)); pollution and degradation of the environment must be avoided, minimised and remedied (s 2(4)(a)(ii)); a risk averse and cautious approach must be applied (s 2(4)(a)(vii)); and environmental management must be integrated, acknowledging that all elements of the environment are interrelated (s 2(4)(b)).

21 S 3. This institution, comprising mainly of stakeholder representatives, informs and advises the Minister of Environmental Affairs and Tourism on: any matter concerning environmental management and governance; and appropriate methods of monitoring compliance with the NEMA Principles.

22 S 7. The object of the committee is to promote the integration and co-ordination of environmental functions by relevant organs of state, and in particular to promote the purpose and objectives of Environmental Implementation Plans and Environmental Management Plans. Its membership comprises of the heads of national and provincial government departments involved with environmental management and its functions 
government departments to prepare environmental implementation plans (EMPs) and/or environmental management plans (EIPs) every four years. ${ }^{23}$ The purpose of these plans is to co-ordinate and harmonise the environmental policies, functions and activities of these departments so as to minimise duplication and promote consistency. ${ }^{24}$ These authorities must exercise their functions that may significantly affect the environment substantially in accordance with these plans and provision is made for annual reporting and enforcing compliance. ${ }^{25}$ Although there is differing recognition in certain EMPs and EIPs of the need for co-operation between departments such as the Department of Environmental Affairs and Tourism (DEAT), the Department of Water Affairs and Forestry (DWAF) and the Department of Agriculture, the current revisions of these plans contain very little guidance regarding how this should practically take place with regard to the regulation of AIPs. ${ }^{26}$ Therefore, although providing a potentially important framework for co-operative environmental governance, it is debatable whether these formal planning and institutional mechanisms are currently of any value in ensuring a co-operative approach to AIP regulation.

In addition to these procedures aimed at achieving co-operative environmental governance, NEMA imposes specific obligations on individuals whose conduct may impact on the environment. Of relevance to the control of AIPs are the provisions regulating environmental impact assessment ${ }^{27}$ (EIA) and those

include investigating and making recommendations on: the assignment and delegation of functions between organs of state under NEMA and any other environmental law; the establishment of mechanisms in each province for integrating authorisation processes; the co-ordinated application of integrated environmental management; and harmonising the environmental functions of all relevant national departments and spheres of government.

23 Ch 3. Various national departments exercising functions that may effect the environment and every province are required to prepare an environmental implementation plan (s 11(1)). National departments exercising functions involving the management of the environment must prepare an environmental implementation plan (s 11(2)). NEMA sets out the mandatory content for each of these plans (s 13 and 14).

$24 \mathrm{~S} 12$.

25 S 16.

26 See eg DEAT Combined Environmental Implementation and Management Plan 8-12, 33, 37 and 41-53; DAWF Combined Environmental Implementation and Management Plan 43, 112 and 136; and Department of Agriculture Environmental Implementation Plan 9, 12, 25, 29-30 and 35.

27 S 24. 
imposing a duty of care on certain categories of people. ${ }^{28}$ With regard to EIA, the government is currently drafting a list of activities for which people are required to undertake an EIA prior to securing permission to proceed with the activity. ${ }^{29}$ These activities notably include the planting and expansion of tree plantations, which predominantly comprise invasive species, the use of any organisms for bio-control and the release of genetically modified organisms. ${ }^{30}$

Regarding the duty of care, any person whose activity causes, may cause or has caused "significant" ${ }^{31}$ pollution or degradation of the environment must take reasonable measures to prevent such pollution or degradation from occurring, continuing or recurring, or in so far as such harm to the environment is authorised by law or cannot reasonably be avoided or stopped, to minimise and rectify such pollution or degradation. ${ }^{32}$ Threats posed by AIP could well fall within the ambit of this duty of care and compel owners, persons in control or who have a right to use the land, to undertake reasonable measures to eradicate or control the spread of these species. ${ }^{33}$ The potential of using these provisions in the context of AIP regulation is unfortunately yet to be tested by administrators and in the courts.

\subsubsection{Environment Conservation Act}

The Environment Conservation Act (ECA) is also of potential relevance to the regulation of AIP for two reasons. Firstly, any person wishing to undertake a

$28 \mathrm{~S} 28$.

29 A draft list of identified activities has been published in GN 12 of 14 January 2005.

30 See Reg 22(15), (22) and (23) respectively.

31 The courts have held that the threshold of "significance" was not particularly high therefore ensuring that the duty of care should have wide application (Hichange Investments $v$ Cape Produce 20041 All SA 655).

32 S 28. NEMA lists the range of persons subject to the duty (s 28(2)) and examples of what constitute "reasonable measures" (s 28(3)). It also allows the relevant authority to issue a directive to any person who fails to undertake these measures. In the event that the person fails to comply with the directive, the relevant authority can take the measures and recover their costs in doing so (s $28(4)$ to s $28(12)$ ). Significantly, this liability would appear to be strict in nature and the duty of care appears to have retrospective operation.

33 This is due to the fact that AIPs have the potential to significantly degrade the environment if one considers their impact on indigenous species, water resources, soil erosion and fire management. 
range of activities relating to the cultivation and importation of AIP must undertake an EIA in terms of the EIA Regulations ${ }^{34}$ prior to doing so. ${ }^{35}$ Secondly, a failure of any person to control or eradicate AIP which in the opinion of a broad range of authorities ${ }^{36}$ may seriously damage, endanger or detrimentally affect the "environment", 37 may be directed to do so under the ECA. ${ }^{38}$ This latter provision has similarly not been utilised in the context of AIP regulation.

\subsubsection{Local Government: Municipal Property Rates Act ${ }^{39}$}

Property tax can significantly influence land-use options and activities of landowners, including those relating to AIPs. The Local Government: Municipal Property Rates Act (Property Rates Act) that regulates municipalities' power to impose property tax, significantly reforms the manner in which property tax is currently levied in South Africa. ${ }^{40}$

The Property Rates Act compels every municipality to adopt an annual rates policy and prescribes a list of factors that they must take into account when doing so. ${ }^{41}$ These factors will ultimately determine the value of any property for

34 GNR 1182-1184 of 5 September 1997, as amended. These EIA Regulations will shortly be repealed when regulations prescribing South Africa's new EIA regime are promulgated under section 24(5) read with section 44 of NEMA.

35 The "intensive husbandry of, or importation of, any plant or animal that has been declared a weed or an invasive species" has been listed as an identified activity (Identified Activity 5) in GNR 1182 of 5 September 1997, as amended. Any person wishing to undertake such an identified activity is required to obtain written authorisation from the provincial environmental authorities prior to doing so (s 22(1)). The authorities cannot issue an authorisation until such time as they have considered an EIA report prepared by the project proponent in accordance with the EIA Regulations (s 22(2)).

36 These authorities include the Minister of Environmental Affairs and Tourism, relevant provincial MEC, local authority or government institution (s 31A(1)).

37 "Environment" is broadly defined as "...the aggregate of surrounding objects, conditions and influences that influence the life and habits of man or any other organisms or collection of organisms" (s 1).

38 See generally s $31 \mathrm{~A}$. If a person fails to comply with the directive, the relevant authority is empowered to take the appropriate measures on the person's behalf $(\mathrm{s} 31 \mathrm{~A}(3))$, after given them an opportunity to be heard, and recover its costs in doing so from the person concerned (s 31A(4)).

39 Local Government: Municipal Property Rates Act 6 of 2004.

40 The Property Rates Act commenced on 2 July 2005.

41 S 3(3). 
rates purposes. A municipality is empowered, in terms of the criteria set out in its rates policy, to levy different rates for different categories of rateable property. ${ }^{42}$ These criteria provide a potential mechanism through which a municipality could implement a differential-rating system to encourage landowners to clear AIPs situated on their land. This could be achieved, for example, by prescribing a favourable rating for those properties where landowners undertake alien-invasive clearing. Various municipalities have already implemented tax benefits of this nature under the previous property tax regime. ${ }^{43}$ Alternatively, this could be achieved by including similar provisions in the national framework governing municipal rates policies that may be prescribed by Treasury in the future. ${ }^{44}$

However, the factors that must be taken into account by a municipality in determining its property rate's policy do not currently include the potential for property rates to be used to achieve the above purpose. The inclusion of various conservation related issues as factors that must be taken into account by any municipality when formulating its rating policy may create the legal framework within which municipalities could develop mechanisms and associated tax incentives, such as preferential rating systems, to reward those landowners who clear AIPs situated on their land. ${ }^{45}$ This approach would also provide the necessary flexibility to enable municipalities to introduce incentives that are appropriate within their given context.

\subsubsection{Provincial and local land-use planning laws}

Since the advent of South Africa's constitutional democracy, there has been a move to integrate social, economic and environmental concerns into provincial

4258.

43 The Bitou Municipality currently offers such a rebate to farmers who clear their land of AIPs (per telecon with Ms Gloria Siko (Bitou Municipality) on 27 July 2005).

44 The Property Rates Act provides for the adoption of a national framework with which all municipal property rates policies must comply (s 3(5)).

45 These issues could include the effect of rates on sustainable land-use and the biodiversity located within municipal boundaries and the need to include appropriate measures to promote and provide tax incentives for conservation and sustainable land-use practices. 
and municipal planning processes. This is of relevance to AIPs regulation as these species raise such concerns and should therefore be integrated within available planning instruments. These planning instruments comprise two main forms, namely integrated development plans (IDPs) and spatial development frameworks (SDFs).

Three laws provide for the adoption of IDPs. These are the Local Government Transition Act, ${ }^{46}$ Local Government: Municipal Structures $\mathrm{Act}^{47}$ and the Local Government: Municipal Systems Act. ${ }^{48}$ IDPs are generally aimed at ensuring the integrated development and management of an area, must be aligned with other relevant national, provincial and local planning frameworks, and must detail institutional and financial arrangements for their implementation. In addition, each IDP must contain the second of the above planning instruments, namely a SDF. SDFs provide the basic framework for each municipality's land use management system. ${ }^{49}$ Many provincial governments are also in the

46 Act 209 of 1993. This Act defines an IDP as “...a plan aimed at the integrated development and management of the area of jurisdiction of the municipality concerned in terms of its powers and duties, and which has been compiled having regard to the general principles contained in Chapter 1 of the Development Facilitation Act 1995, and where applicable, having regard to the subject matter of a land development objective contemplated $n$ terms of Chapter 4 of that Act" (s 10B). All municipalities must develop and implement an IDP for its area of jurisdiction (s 10D(4)(b)). In addition, the district councils must: prepare a financial plan regarding the implementation of the IDP; monitor its implementation; and report its progress to its community (s $10 \mathrm{G}(1)$ (c, f and g).

47 Act 117 of 1998. This Act defines an IDP as a "...plan aimed at the integrated development and management of a municipal area" (s 1). Municipalities are obliged to ensure integrated development planning within their area (s 83(3)(a)) and they can adopt an IDP to achieve this purpose (s 30(5)(b)).

48 Act 32 of 2000 . Ch 5 of the Act is dedicated to the planning, drafting, adoption and implementation of IDPs. Every municipality must adopt an IDP (s 25) which must be aligned with, and complement, other relevant planning frameworks administered by organs of state in order to achieve the progressive realisation of various fundamental rights (including the environmental right) and give effect to the constitutional principles of cooperative government (see s 23 and s 24 generally). An IDP adopted by a municipality is the key strategic instrument which must guide and inform all planning and development, and all decision with regard to planning, management and development in the municipality (s 35(1)(a) and (b)). The details regarding the content and implementation of these IDPs are set out in the Local Government: Municipal Planning and Performance Management Regulations published in GNR 796 of 24 August 2001.

49 S 26(e). The Local Government: Municipal Planning and Performance Management Regulations prescribe the minimum content for these SDFs which include setting basic guidelines for a land use management system in the municipality and complying with the general principles for land development set out in ch 1 of the Development Facilitation Act 67 of 1995 (see Reg 2 generally). The general principles for land development crucially provide that policy, administrative and laws should encourage and promote sustainable 
process of formulating and adopting provincial SDFs. ${ }^{50}$ Although not statutorily prescribed to do so, these spatial development frameworks provide important opportunities for provinces to prescribe a context for the adoption of municipal IDPs and SDFs.

Given the problems with the practical implementation of many of the national planning frameworks and the lack of current alignment of municipal functions with those of provincial and national authorities, it is hoped that these future provincial and municipal planning frameworks will contribute towards this necessary alignment. Although the laws regulating the content and adoption of these plans make no specific provision for the integration of AIP regulation, many conservation laws expressly do so. ${ }^{51}$

\subsection{Biodiversity conservation}

South Africa currently ranks as the third most biologically diverse country in the world. $^{52}$ It has nine times more plants, eight times more breeding birds, six times more mammals, twice as many amphibians and six times as many reptile species as the mean for all countries worldwide. ${ }^{53}$ South Africa's celebrated biodiversity is, however, currently one of the most threatened on the planet and the rapid spread of AIPs pose one of the greatest threats. ${ }^{54}$

land development practices and processes through, inter alia, promoting the sustained protection of the environment (s 3(1)(c)(viii) and s 3(1)(h)(iii)).

50 Examples include: Gauteng; Kwazulu-Natal; North West (Draft); and Western Cape (Draft).

51 The Biodiversity Act provides that biodiversity management plans must be consistent with municipal IDPs (s 48(2)) which must in turn integrate invasive species control plans (s 76). In addition the Protected Areas Act provides that a management plan adopted for a protected area must take into account any applicable aspects of relevant municipal IDPs (s 39(4)).

52 See further DEAT White Paper on the Conservation and Use of South Africa's Biodiversity 12.

53 DEAT Environmental Impacts of Invading Alien Plants in South Africa 13.

54 Preston and Siegfried 1995 Journal of Wildlife Research 49. See generally Richardson and Van Wilgen 2004 South African Journal of Science 45. 
National and provincial governments have promulgated a complex and largely un-coordinated network of laws to manage the threats posed to South Africa's diversity of flora and fauna. ${ }^{55}$ These laws generally adopt traditional legal techniques to conserve and manage biodiversity ${ }^{56}$ and are administered by a wide range of institutions. ${ }^{57}$ This array of legislation has proven inept in halting the demise of South Africa's biodiversity and does not adequately deal with AIPs. The government has recently promulgated the National Environmental Management: Biodiversity $\mathrm{Act}^{58}$ (Biodiversity Act) and National Environmental Management: Protected Areas Act ${ }^{59}$ (Protected Areas Act) to rationalise the current fragmented approach.

\subsubsection{National Environmental Management: Biodiversity Act}

The Biodiversity Act radically reforms South Africa's biodiversity conservation legislation and contains provisions of general and specific relevance to the control of AIPs. The government is appointed as trustee of South Africa's biodiversity $^{60}$ and the Biodiversity Act prescribes a three-tier planning framework to manage biodiversity. These are the national biodiversity framework, ${ }^{61}$ bioregional plans ${ }^{62}$ and biodiversity management plans, ${ }^{63}$ all three

55 Acts which are of relevance include the NEMA, ECA, NWA, CARA, MCAA, World Heritage Convention Act 49 of 1999, National Heritage Resources Act 25 of 1999, National Forests Act 84 of 1998, Animal Improvement Act 62 of 1998, Marine Living Resources Act 18 of 1998, Genetically Modified Organisms Act 15 of 1997, Forest Act 122 of 1984, Plant Improvement Act 53 of 1976, Plant Breeders' Rights Act 15 of 1976 and various provincial conservation and land-use planning Ordinances and Acts.

56 These include: prescribing a network of protected areas; listing species; permitting requirements; and EIA requirements. The majority are based on the command and control approach in terms of which the government seeks to penalise non-compliance as opposed to offering incentives to secure compliance.

57 These include: DEAT; DWAF; Department of Agriculture; South African National Parks; South African National Biodiversity Institute; provincial environmental departments, provincial conservation authorities; and local government authorities.

58 Act 10 of 2004.

59 Act 57 of 2003 (as amended by National Environmental Management: Protected Areas Amendment Act 31 of 2004).

60 S 3.

61 The Minister of Environmental Affairs and Tourism must within thee years prepare a national biodiversity framework: providing for an integrated, co-ordinated and uniform approach to biodiversity management by organs of state in all spheres of government, non-governmental organizations, the private sector, local communities and the public; 
of which should be of relevance to the future regulation of AIPs in South Africa given their broadly defined content. Importantly, the Biodiversity Act provides that the above planning instruments may not conflict with various existing planning instruments such as EMPs and EIPs prepared under NEMA, integrated development plans adopted under the Local Government: Municipal Systems $\mathrm{Act}^{64}$ and any other relevant spatial development frameworks prepared in terms of national or provincial legislation. ${ }^{65}$ Conversely, the Biodiversity Act also provides that any EIPs, EMPs or IDPs prepared after the publication of national biodiversity framework or bioregional plan, must be aligned with the latter biodiversity planning framework. ${ }^{66}$ The South African National Biodiversity Institute (SANBI) may assist the organs of state in achieving this alignment. ${ }^{67}$ It is unfortunate that this task is discretionary and it remains to be seen whether SANBI has the capacity and resources to fulfil this task. Surely it would have been preferable to assign this responsibility to an entity such as the CEC which has already been mandated under the NEMA to achieve integration of this nature at a national level. Alternatively, it would have been advisable to prescribe clear procedures for this alignment.

Chapter 5 of the Biodiversity Act deals specifically with species and organisms posing potential threats to biodiversity. The Act draws a distinction between "alien species"68 and "invasive species" 69 which are subject to different regulation.

identifying priority areas for conservation action and reflect regional co-operation on issues concerning biodiversity management in Southern Africa (s 38 and s 39).

62 The Minister or MEC for environmental affairs in any province may determine an area as a bioregion (if a region contains whole or several nested ecosystems and is characterised by its landforms, vegetation cover, human culture and history) and publish a plan for the management of biodiversity in that area (s 40).

63 Any person, organisation or organ of state desiring to contribute to biodiversity management may submit to the Minister or MEC a biodiversity management plan aimed at ensuring the long-term survival in nature of the species or ecosystem (s 43).

64 Act 32 of 2000 .

65 S 48(1).

$66 \quad S 48(2)$.

67 S 48(3).

68 "Alien Species" are defined as "(a) a species that is not an indigenous species; or (b) an indigenous species translocated or intended to be translocated to a place outside its natural distribution range in nature, but not an indigenous species that has extended its natural distribution by natural means of migration or dispersal without human intervention" (s 1). 
Alien species are regulated through three main mechanisms. Firstly, a person wishing to undertake certain defined "restricted activities" regarding a specimen of an alien species must obtain a permit ${ }^{70}$ unless he or she has been exempted from doing so. ${ }^{71}$ The permit may only be issued after a "prescribed assessment" of the risks and potential impacts has been carried out and it therefore appears that the Act envisages the development of a specialised EIA process to regulate this permitting process. ${ }^{72}$ This is not desirable given the high degree of fragmentation already plaguing South Africa's EIA regime. ${ }^{73}$ It would be far more preferable to integrate the EIA process within that to be prescribed under NEMA in the near future.

Secondly, the Biodiversity Act allows the Minister to publish a list of alien species in respect of which "restricted activities" are absolutely prohibited. Provision is made for the regular review of this list. ${ }^{74}$ Finally, the Act imposes a duty of care on any person seeking to undertake a restricted activity involving an alien species whether permitted to do so or not. ${ }^{75}$ This duty of care is very

69 "Invasive species" are defined as "...those whose establishment and spread outside of its natural distribution range - (a) threaten ecosystems, habitats or other species or have demonstrable potential to threaten ecosystems, habitats or other species; and (b) may result in economic or environmental harm or harm to human health" (s 1).

70 S 65. These "restricted activities" are defined to include activities such as: importing; exporting; growing; propagating; conveying, or having alien species in their possession (s 1).

71 The Minister is empowered to exempt certain alien species from the permitting requirements prescribed in the Act (s 66(1)). A person can undertake a restricted activity involving a specimen of an alien species without a permit (s 66(2)).

72 "Prescribed" is defined as "...prescribe by way of regulation in terms of s 97" of the Biodiversity Act (s 1). It therefore appears that the intention of the legislature is to develop an entirely separate EIA system under the Biodiversity Act, and not to integrate this EIA process with that to shortly be prescribed by way of regulation under ch 5 of NEMA, as amended by the National Environmental Management Amendment Act 8 of 2004.

73 Distinct EIA principles, requirements and procedures are fragmented through many current laws including: ECA and EIA Regulations; Outeniqua Sensitive Coastal Area Regulations promulgated under the ECA (GN R879 of 31 May 1996, as amended); Pennington \& Untamvuna Sensitive Coastal Area Regulations promulgated under the ECA (GNR 1529 of 27 November 1998, as amended); Off-Road Vehicle Regulations promulgated under the ECA (GNR 1399 of 21 December 2001); Mineral and Petroleum Resources Development Act 50 of 1991(s 22); National Heritage Resources Act 25 of 1999 (s 38); Marine Living Resources Act 18 of 1998 (s 18(3)); and NWA (s 41).

74 S 67. See n 70 above regarding the range of "restricted activities".

75 S 69. Persons permitted to undertake restricted activities must comply with their permitting conditions and take all required steps to prevent or minimise harm to biodiversity. Relevant authorities can issue a written directive to any person who has failed to comply with the 
similar to that prescribed under NEMA but unfortunately does not prescribe a procedure to compel the relevant authority to issue a directive to a person who fails to comply with the duty of care. ${ }^{76}$

Invasive species are subject to far stricter regulation. The Minister and provincial MECs are empowered to publish national and provincial lists of invasive species respectively. ${ }^{77}$ Unfortunately the Biodiversity Act does not prescribe an interim list of invasive species pending the publication of the above list. Therefore, the following provisions regulating these invasive species will be inoperative until such time as it has been published. ${ }^{78}$

As with alien species, no person may undertake a restricted activity involving a specimen of a listed species without a permit. ${ }^{79}$ The issuing of a permit must similarly be preceded by a "prescribed assessment of risks and potential impacts on biodiversity". ${ }^{80}$ A duty of care is imposed on both permit holders and landowners on whose land listed invasive species occur. ${ }^{81}$ However, the content of this duty of care is far broader than that relating to alien species ${ }^{82}$ and provision is made for persons to approach the court in the event that the

above or who has illegally undertaken a restricted activity (without a permit) or a totally prohibited activity. As under the NEMA, if that person fails to comply with the directive, the relevant authority can implement the directive and recover their costs in doing so. In addition, if an alien species established itself in nature as an invasive species because of the actions of a specific person, the relevant authority can hold that person liable for any costs incurred in the control and eradication of that species (s 69(4). This appears to be the case irrespective of where the AIPs are located or whether a directive has been issued by the authority concerned.

76 See s 28(12) of NEMA for a procedure of this nature. See further Soltau 1999 SAJELP 43 for a comprehensive discussion on s 28 of NEMA.

77 S 70.

78 The Minister is compelled to publish such a list by 1 September 2006 (s 70(1)(a)). Provincial MECs have discretion to publish a list of invasive species and no time limits are prescribed within which they are required to do so (s 70(1)(b)).

79 S 71(1).

80 S 71(2).

81 S 73.

82 The obligations include: notifying the relevant authorities, in writing, of listed invasive species occurring $\mathrm{n}$ their land; taking steps to control and eradicate the listed invasive species and to prevent it from spreading; and taking all required steps to prevent or minimise harm to biodiversity (s 73(2)). 
relevant authorities do not issue a directive to a person who fails to fulfil his/her duty of care. ${ }^{83}$

In addition, many institutions are required to prepare and incorporate invasive species control and eradication strategies in various planning mechanisms prescribed by other legislation. ${ }^{84}$ These strategies provide important opportunities to align these institutions' planning frameworks. Provision is also made for certain of these institutions to submit invasive alien species reports at regular intervals to the Minister or relevant MEC. ${ }^{85}$ Unfortunately, this requirement is limited to management authorities appointed under the Protected Areas Act and it is unclear what interval constitutes "regular" reporting. This aspect, and the contents of these strategies, will hopefully be prescribed by regulation.

Finally, the Act imposes a range of obligations on the manner in which listed invasive species can be controlled and eradicated. ${ }^{86}$ These crucially include: the control method must be appropriate for the species and the environment concerned; control must be executed with caution and in a manner that may cause the least possible harm to biodiversity and damage to the environment; and the method adopted must be directed at the adult plants and their offspring to prevent re-growth. Given that control measures often have significant environmental consequences and in certain circumstances can be more harmful than the AIPs themselves, it is hoped that DEAT will prescribe additional detailed guidelines regarding what constitute appropriate control measures. The Minister is tasked with ensuring the co-ordination and implementation of programmes for the prevention, control and eradication of invasive species and may establish an entity consisting of public servants to co-

$83 \mathrm{~S} 74$. This provision is identical to that contained in s 28(12) of NEMA.

84 S 76 and 77. These include: management authorities appointed to manage protected areas under the Protected Areas Act (s 39); organs of state required to prepare EIPs and EMPs under NEMA (s 11); and municipalities required to prepare integrated development plans under the Local Government: Municipal Structures Act 117 of 1998.

85 S 77.

86 S 75. 
ordinate and implement these programmes. ${ }^{87}$ Once again, no clear guidance is provided on how this co-ordination should take place, what the functions and powers of the "entity" will be and how it will be funded.

The permitting provisions in the Biodiversity Act are also of particular relevance in the context of AIP regulation. ${ }^{88}$ Firstly, additional requirements are imposed on persons seeking to undertake restricted activities relating to alien and listed invasive species. The relevant authority may only issue a permit if: adequate procedures have been followed by the applicant to assess the risks and potential impacts associated with the restricted activity; the relevant species has been found to have negligible or no invasive potential; the benefits of allowing the activity are significantly greater that the costs associated with preventing or remedying any damage to the environment or biodiversity; and it is satisfied that adequate measures have been taken by the applicant to prevent the escape and spread of the species. ${ }^{89}$ No clear guidelines are provided regarding what would constitute "adequate" procedures or measures in the above circumstances. This detail will hopefully be prescribed by way of regulation. Secondly, provision is made for integrated permitting, crucial in light of the fact that many of the restricted activities requiring a permit under the Biodiversity Act may also require some form of formal authorization under other environmental legislation. ${ }^{90}$

The Biodiversity Act therefore prescribes a wide range of planning frameworks and tools to regulate AIP. However, there are many potential problems associated with their implementation. The Biodiversity Act provides very little guidance on the content of the duty of care, the control methods to be adopted in clearing AIP and the EIA procedure to be followed when undertaking a restricted activity. Fortunately, the Minister has discretion to prescribe the

87 S 75(4) and (5).

88 See ch 7 generally.

89 S 91.

90 S 92. These laws could include the NEMA (s 24), NWA (s 22), ECA (s 22) and the CARA Regulations. 
necessary detail by way of regulation ${ }^{91}$ and given that different areas and species often require varying forms of regulation, provision is made for differentiated regulation between persons, areas and species. ${ }^{92}$

A further concern relates to the alignment and co-ordination of the Biodiversity Act's provisions with those contained in other relevant legislation. Although appearing satisfactory with regard to planning, very little guidance is provided as to how the remainder of the Biodiversity Act should be aligned and coordinated with relevant overlapping provisions in NEMA, ${ }^{93}$ the ECA, ${ }^{94}$ National Water Act ${ }^{95}$ (NWA), Conservation of Agricultural Resources Act ${ }^{96}$ (CARA), Mountain Catchment Areas Act $^{97}$ (MCAA) and National Veld and Forest Fire Act $^{98}$ (NV\&FFA), Plant Improvement Act $^{99}$ and relevant provincial legislation, for example. The result appears to be the addition of yet another corridor of fragmentation within an already chaotically fragmented legislative maze. The Alien Invasive Regulations, currently being drafted by the DEAT, provide a valuable opportunity to attempt to remedy this fragmentation. ${ }^{100}$

91 S 97 lists a broad range of issues in respect of which the Minister may make regulations. These include: the facilitation of the enforcement of provisions regulating restricted activities undertaken vis a vis alien species and listed invasive species (s 97(1)(c)(iii))); the prescription of permitting conditions issued to undertake these activities (s 97(1)(c)(iv)); the assessment of risks and potential impacts on biodiversity of restricted activities involving specimens of alien species or of listed invasive species (s 97(1)(c)(v)); and the control and eradication of listed invasive species (s 97(1)(c)(vi)).

$92 \mathrm{~S} 98(1)(\mathrm{c})$.

93 See s 24 (EIA) and s 28 (duty of care) in particular. The Biodiversity Act merely provides that the Biodiversity Act must be read with any applicable provisions of NEMA and that conflicts must be resolved in terms of Chapter 4 of NEMA. It does not provide any real guidance regarding how this should take place in practice.

94 See s 22 read with the EIA Regulations (GNR 1182-1184 of 5 September 1997, as amended) and s $31 \mathrm{~A}$ (duty of care).

95 See s 22 (permissible water uses).

96 See Regs 15-16 of the CARA Regulations (GNR 1048 of 25 May 1984, as amended).

97 Act 63 of 1970.

98 Act 101 of 1998.

99 Act 53 of 1976.

100 DEAT is currently drafting Alien Invasive Regulations under s 97 of the Biodiversity Act. These regulations will provide: procedures that prohibit, restrict or allow the importation into South Africa of alien species; measures for the prevention, eradication or control of alien and invasive species occurring within the Republic; the enforcement of the Act and the regulations; penalties in respect of contraventions; and for incentives in respect of compliance with the Act and regulations in relation to alien and invasive species. The regulations are due to be published for comment in the first half of 2006. 


\subsubsection{National Environmental Management: Protected Areas Act}

South Africa's protected area's regime is currently governed by sixteen national and provincial laws ${ }^{101}$ providing for the declaration of seventeen different types of statutory terrestrial protected areas administered by twelve different conservation authorities. In an effort to rationalise this fragmentation, the government has recently introduced the Protected Areas Act which repeals certain key protected areas legislation and reform South Africa's protected areas regime. $^{102}$

Although not principally concerned with the control of AIPs, South Africa's new protected areas legislation is of potential relevance for various reasons. Firstly, many of the objectives for which protected areas are declared impact on the regulation of AIPs located within or adjacent to them. These objectives include: conserving biodiversity, ecological integrity and threatened and protected species and ecosystems; ${ }^{103}$ regulating the conservation, use, management and control of land situated in mountain catchment areas; ${ }^{104}$ promoting the preservation of specific ecological processes, natural systems, natural beauty or species of indigenous wildlife; ${ }^{105}$ and protecting the environment generally. ${ }^{106}$

The declaration of protected areas to achieve certain objectives is essential. Of greater importance, however, is the prescription of efficient management regimes to ensure that these objectives are met. It is in this regard that the Protected Areas Act is of great value as it introduces a comprehensive

101 These include the: Lake Areas Development Act (39 of 1975); MCAA; ECA; Forest Act; National Forests Act; World Heritage Convention Act; National Heritage Resources Act; and several provincial conservation Ordinances and Acts.

102 The provisions in the ECA that allow for the establishment of special nature reserves (s 18) were repealed with effect from 1 November 2004. The provisions in the ECA that allow for the establishment of special nature reserves (s 16 and 17) are repealed in provinces with effect from the date the province promulgates regulations, under the Protected Areas Act, governing special nature reserves situated within their provincial boundaries. The National Parks Act, which regulated national parks, was repealed with effect from 1 November 2005, the date on which the National Environmental Management: Protected Areas Amendment Act 31 of 2004 came into force.

103 S 17 of the Protected Areas Act.

104 Preamble to the MCAA.

$105 \mathrm{~S} 16(1)(\mathrm{a})$ of the ECA.

$106 \mathrm{~S} 18(2)(\mathrm{a})$ of the ECA. 
management framework largely absent in current protected areas legislation. The authorities empowered to declare protected areas under the Act are required to assign the management of the protected area to a management authority. ${ }^{107}$ The management authority is required to prepare and submit a management plan for approval. ${ }^{108}$ The content of the management plan will effectively identify the conservation-related activities to be undertaken by the management authority and must include an alien invasive control plan. ${ }^{109}$ Crucially, provision is made for monitoring compliance with these plans ${ }^{110}$ and terminating management mandates where the appointed authorities do not satisfactorily implement them. ${ }^{111}$ The relevant authorities should, therefore, have the necessary tools to ensure that issues relating to the control of AIPs are integrated into these management frameworks and implemented by the relevant management authorities. Significantly, provision is made for the alignment of these management plans with various other planning frameworks of relevance to AIPs. ${ }^{112}$

$107 \mathrm{~S} 38$.

108 S 39.

$109 \mathrm{~S} 76(1)$ of the Biodiversity Act prescribes that management plans prepared by management authorities must incorporate an alien species control plan. $110 \mathrm{~S} 43$.

111 S 44.

112 The Protected Areas Act contains three provisions which provide for alignment in the context of AIPs. Firstly, the Act provides that it should be aligned with applicable provisions of NEMA (s 5). These would include the NEMA principles and those relating to EMPs and EIPs. Secondly, it provides that the Act must be read interpreted and applied in conjunction with the Biodiversity Act (s 6). This would include the various planning mechanisms prescribed in the latter Act. Finally, the Protected Areas Act provides that management plans prepared by management authorities must take into account any applicable aspects of relevant integrated development plans prepared by the municipality in which the protected area is situated (s 39(4)). The Protected Areas Act compels management authorities, when preparing a management plan, to consult municipalities, other organs of state, local communities and other affected parties which have an interest in the area. This should ensure that the provisions in any management plan relating to AIPs are aligned with the efforts of other role players involved in AIP Regulation such as Catchment Management Agencies, municipalities and fire protection associations (s 39(3)). 


\subsubsection{Provincial legislation}

Although provincial Ordinances and Acts predominantly regulate AIPs in the aquatic context, ${ }^{113}$ there is an increasing tendency in recent provincial legislation to regulate AIPs in a far broader way. The Mpumalanga Nature Conservation Act, ${ }^{114}$ for example, lists a range of AIPs in respect of which the possession, sale, purchase, donation, receipt, conveyance, importation and cultivation is prohibited. ${ }^{115}$ Owners and occupiers of land upon which listed AIPs are found and which threaten the natural biodiversity, must eradicate or destroy them. ${ }^{116} \mathrm{~A}$ failure to comply with these provisions attracts criminal liability. ${ }^{117}$ Although desirable to have such stringent regulation, there appears to be unnecessary duplication at national and provincial level.

\subsection{Water conservation}

Water scarcity is perhaps one of the greatest challenges facing South Africa. ${ }^{118}$ The problem is compounded by AIPs which, according to current estimates, consume around 3.300 billion $\mathrm{m}^{3}$ of water per year, about seven percent of South Africa's mean annual runoff. ${ }^{119}$ This consumption is nearly equal to total domestic and industrial consumption in South Africa's major urban and industrial centers. ${ }^{120}$ It is therefore essential that South Africa's two main laws aimed at conserving the country's water resources, the NWA and MCAA, satisfactorily address the threats posed by AIPs.

113 See the discussion below regarding the legal framework regulating AIPs in the context of water conservation.

114 Act 10 of 1998.

115 S 80(3) read with Schedule 13.

116 S 80(4).

117 S 80(5).

118 South Africa's average annual rainfall is $497 \mathrm{~mm}$, well below the world average of $860 \mathrm{~mm}$. This is compounded by the fact that owing to high evaporation rates only $8.6 \%$ of the rainfall is available as surface water. This is one of the lowest conversion ratios in the world. South Africa accordingly has very scarce water resources. See generally DEAT State of the Environment Report 1999.

119 DEAT Environmental Impacts of Invading Alien Plants in South Africa, 8. See further WfW Annual Report (2003/2004) 10.

120 Shine, Williams and Gündling Designing Legal and Institutional Frameworks 9. 


\subsubsection{National Water Act}

The purpose of the NWA is to ensure that the nation's "water resources"121 are protected, used, developed, conserved, managed and controlled to achieve various ends including: promoting equitable access to water; redressing past inequalities; promoting sustainable use; facilitating social and economic development; protecting aquatic ecosystems; and reducing and preventing pollution. ${ }^{122}$ Although one would expect the NWA to provide for the regulation of AIPs in the context of water resource management, the Act contains no express reference to these species.

Nonetheless, the NWA contains a number of provisions of relevance to the regulation of AIPs. Firstly, it prescribes a range of water management strategies that once finalised, will prescribe the framework within which water resources will be managed. ${ }^{123}$ These include a National Water Resource Strategy (NWRS) ${ }^{124}$ and regional Catchment Management Strategies. ${ }^{125}$ The NWRS makes express reference to the impact of AIPs on South Africa's scarce water resources and calls for a "coordinated multi-sectoral" management approach. ${ }^{126}$ From a water resource management perspective, the NWRS envisages that AIP control should be undertaken at catchment management

121 The term "water resources" is exceptionally broadly defined to include a watercourse, surface water, estuary or aquifer. The term "water course" is in turn defined as " ...(a) a river or stream; (b) a natural channel in which water flows regularly or intermittently; (c) a wetland, lake or dam into which, or from which, water flows; and any collection of water which the Minister may, by notice in the Gazette, declare to be a watercourse, and ... includes, where relevant, its beds and banks" (s 1).

122 S 2.

123 Ch 2.

124 The Minister of Water Affairs and Forestry is responsible for developing the NWRS that provides the framework for the protection, use, management and control of water resources for the country as a whole. The strategy is binding on authorities and institutions exercising powers or performing functions under the Act. See ch 2 (part 1) generally.

125 South Africa has been divided into eight different catchment management areas and a catchment management agency (CMA) will be appointed for each of these areas. These CMAs must develop a catchment management strategy for the water resources within their water management area. These catchment management strategies must be in harmony with the national strategy and must set principles for allocating water to existing and prospective users, taking into account all matters relevant to the protection, use, development, conservation and management of water resources in their area. See ch 2 (part 2) generally.

126 DWAF National Water Resources Strategy (First Edition) 81. 
level and may be prioritised in specific catchment management strategies. ${ }^{127}$ In addition, it provides that where vegetation clearing activities contribute to improved water security the costs may be funded by water management institutions using water resource management charges on water users. ${ }^{128}$

The above should ensure that questions of AIP regulation filter down to the myriad other planning measures designed to protect water resources ${ }^{129}$ as each of these subsidiary instruments must comply with the framework prescribed in the NWRS. However, the absence of any clear guidelines regarding how this should be achieved is a concern. A further shortcoming is that very little provision is made for the alignment of the above strategies with those prescribed in other legislation of relevance to AIP regulation. ${ }^{130}$

Secondly, the measures aimed at preventing pollution ${ }^{131}$ are also of potential relevance to the regulation of AIP given the broad definition of "pollution". 132 Thirdly, certain activities relating to AIP may constitute a "water use" and

129 These include the development of a system to classify the nation's water resources (ch 3 (part 1)), the setting of resource quality objectives for different categories of water resources (ch 3 (part 2)) and determining the Reserve for each class of water resource (ch 3 (part 3)). This Reserve will consist of two components - the basic human needs component (the quantity and quality of water necessary to provide for the basic needs of individuals served by the water resource) and the ecological reserve (the quantity and quality of water necessary to protect aquatic ecosystems of the water resource). The class, resource quality objectives and Reserve, once determined, will bind any authority exercising a power or performing a function under the Act. These measures have not yet been determined by the Minister.

130 The NWA only provides that Catchment Management Strategies must take account of any relevant national or regional plans prepared in terms of any other law (s 9(f)). Unfortunately no guidance is provided regarding how this should practically take place.

131 Any person who owns, controls, occupies or uses the land where pollution of a water resource occurs, or might occur, as a result of activities on the land, must take measures to prevent the pollution occurring. If they fail to do so, the relevant CMA may itself do whatever is necessary to prevent the pollution or to remedy its effects and recover all reasonable costs from persons responsible for the pollution. See Chapter 3 (Part 4).

132 "Pollution" is defined to include "...the direct or indirect alteration of the physical, chemical, or biological properties of a water resource so as to make it - (a) less fit for any beneficial purpose for which it may reasonably be expected to be used; or (b) harmful or potentially harmful - (aa)...(cc) to the resource quality..." (s 1). "Resource quality" is defined as the quality of all the aspects of a water resource including "...the quantity, pattern, timing, water level and assurance of instream flow" (s 1). The impact of AIPs could well fall within this definition given their impact on water resources. 
therefore be subject to the provisions regulating water use in the Act. ${ }^{133}$ The general rule is that no one may use water unless: it has been declared a de minimus use; $;^{134}$ it is subject to a general authorisation; ${ }^{135}$ it constitutes a continuation of existing lawful water uses; ${ }^{136}$ or the use has been licensed or exempted. $^{137138}$ Finally, certain activities relating to AIPs may constitute offences under the NWA. ${ }^{139}$

Although appearing to prescribe a number of planning frameworks and mechanisms that could be utilised to regulate AIP in the context of water resource management, the extensive delays in the implementation of many of the essential planning frameworks ${ }^{140}$ and the establishment of key water management institutions ${ }^{141}$ currently undermine their effectiveness.

133 The term "water use" is exceptionally broadly defined to include engaging in certain prescribed "stream flow reduction activities" (s 21(d)). These "stream flow reduction activities", regulated by s 36 , currently included the "...use of land for afforestation which has been or is being established for commercial purposes" (s 36(1)(a)). Given that these commercial plantations generally comprise of alien tree species, they will be subject to the water use provisions under the NWA (ch 4).

134 These uses are set out in Schedule 1 of the NWA and include using water for reasonable domestic purposes, recreational purposes and emergency situations.

135 The Minister or CMA may permit certain types of water use by publishing general authorisations in the Government Gazette. Certain general authorisations have been published to date (GN 398 of 26 March 2004). See generally ch 4 (part 6).

136 The NWA permits the continuation of certain existing water uses which were permitted under laws repealed by it. See generally ch 4 (part 3).

137 The NWA contains detailed guidelines and procedures regulating the issuing of licenses and exemptions. See generally ch 4 (parts 2, 7, 8 and 9).

138 S 4 read with s 22 .

139 These activities could include: fail to comply with any condition attached to a permitted water use; fail to comply with a directive issued under $s$ 19; and unlawfully and intentionally or negligently commit and act or omission which pollutes/detrimentally affects or is likely to pollute/affect a water resource (s 151(i) and (j)). Given the detrimental impacts AIPs have on water resources and the broad definition afforded to "water use" and "pollution" under the NWA, many activities relating to these species could be held to constitute an offence under the Act.

140 The NWRS was only published in September 2004 six years after the NWA came into force. The classification system, resource quality objectives and reserve are yet to be finalised.

141 Only two CMAs (Nkomati CMA and Breede/Overberg CMA) have been established since the NWA came into force. A further six proposals have been submitted to DWAF for approval. See DWAF http://www.dwaf.gov.za/Documents/ 15 Apr. 


\subsubsection{Mountain Catchment Areas Act}

Twenty percent of land in South Africa, the majority of which is situated in mountainous areas, generates eighty percent of South Africa's streamflow. ${ }^{142}$ Unfortunately, many of these mountain catchment areas are inundated with alien invasive vegetation which poses serious threats to water security in South Africa. ${ }^{143}$ The MCAA, administered by the provincial environmental authorities, ${ }^{144}$ was enacted to provide for the conservation, use, management and control of land situated in mountain catchment areas. ${ }^{145}$

The Act provides for the declaration of mountain catchment areas ${ }^{146}$ and the issuing of directions with reference to land situated both within an area so declared and within five kilometers from its boundary. ${ }^{147}$ These directions may relate to the conservation, use management and control of such land including the destruction of "intruding vegetation". ${ }^{148}$ Provision is made for the payment of compensation to landowners and occupiers of land in respect of monetary loss incurred in complying with the terms of any such direction. ${ }^{149}$ The Act also makes it an offence for any person to refuse or fail to comply with a direction. ${ }^{150}$ An additional incentive granted to landowners whose land has been incorporated within a mountain catchment area is that it will be exempt from property tax. ${ }^{151}$

142 DEAT Environmental Impacts of Invading Alien Plants in South Africa 7.

143 Davies and Day Vanishing Waters 315.

144 Procl R28 of 7 April 1995.

145 See the long title of the Act.

$146 \mathrm{~S} 2$. To date only six percent of privately owned mountain catchments (which constitute eighty five percent of all mountain catchments in South Africa) have been declared as mountain catchment areas under the MCAA. See Rabie and Burgers 1997 SA Public Law 357.

147 S 3.

148 The term "intruding vegetation" is not defined but would presumably include AIPs.

$149 \mathrm{~S} 4$.

$150 \mathrm{~S}$ 14. The penalties are, however, exceptionally limited and include a fine not exceeding R1000 and/or imprisonment for a period not exceeding two years. 151 S 5. 
Although seeming to provide valuable tools to regulate AIPs only nine mountain catchment areas have been declared to date, predominantly in the Western Cape, and not one direction has been issued. ${ }^{152}$

\subsubsection{Provincial legislation}

Provincial Nature Conservation Ordinances and Acts predominantly deal with wildlife protection. However, the majority also regulate AIPs in the context of water resource protection in that they prohibit the cultivation, possession, transportation, sale, donation, purchase, import or acquisition of any "noxious aquatic growths" generally defined to include a very limited array of species such as Water Hyacinth, Parrot's Feather and Water Ferns. ${ }^{153}$ The enforcement of these provisions has not, however, been consistent or effective. ${ }^{154}$

\subsection{Agricultural management}

AIPs often invade prime agricultural land, deplete soil of valuable nutrients and change the soil's nutrient balance. The result of these alien invasions is that vast tracts of previously valuable agricultural land become unsuitable for agriculture purposes. In addition, AIPs kill off indigenous groundcovers which slow water run-off and prevent soil erosion. The absence of these indigenous groundcovers increases the speed of water run-off which in turn intensifies erosion and flooding. This has led the Minister of Agriculture to state that

152 Per telecon with Jenny Nicholson (Cape Nature Legal Advisor) on 27 January 2006. See further Rabie and Burgers 1997 SA Public Law 358.

153 See eg: s 60 read with Schedule 5 of the Western Cape Nature Conservation Laws Amendment Act 2004; s 85 read with Schedule 10 of the Gauteng Nature Conservation Ordinance 12 of 1983; and s 68 read with Schedule 10 of the Mpumalanga Nature Conservation Act 10 of 1998.

154 In the Western Cape, for example, the provincial conservation authorities have never enforced these provisions relating to "noxious plants" (per telecon with Jenny Nicholson (Cape Nature Legal Advisor) on 27 January 2006. 
...one of the biggest threats to the sustainability of agricultural practices is AIPs.

South Africa's key agricultural legislation, CARA and the Regulations promulgated under it ${ }^{156}$ (CARA Regulations) currently provide the main tool for directly regulating AIPs in South Africa. ${ }^{157}$ Although originally enacted to deal specifically with AIPs in the context of agriculture, the CARA Regulations have been applied to regulate these species' impact on biodiversity conservation, water resource management and fire management in the absence of alternate relevant legislation. The government is in the process of reviewing CARA which will ultimately be repealed by the Sustainable Use of Agricultural Resources Draft Bill (SUAR Bill) currently being drafted by the Department of Agriculture.

\subsubsection{Conservation of Agricultural Resources Act}

The objects of CARA, administered by the Department of Agriculture, include

...the conservation of the natural agricultural resources of the Republic by the maintenance of the production potential of land [...] and by the protection of the vegetation and the combating of weeds and invader plants. ${ }^{158}$

The Act empowers the Minister of Agriculture to declare plants as "weeds"159 and "invader plants" 160 throughout the country or in respect of one or more areas. $^{161}$ The Minister exercised these powers and published the CARA

155 Didiza "Invasive Species" 5.

156 GNR 1048 of 25 May 1984, as amended by GNR 280 of 30 March 2001.

157 Although the Biodiversity Act also provides directly for the regulaiton of AIPs, its provisions will only become effective once the Minister has listed invasive species and promulgated regulations to give effect to the Act's broad provisions. This is schedule to take place before the end of 2005.

158 S 3.

159 "Weed" is defined as "... any kind of plant which has under s 2(3) been declared a weed, in includes the seed of such plant and any vegetative part of such plant which reproduces itself asexually" (s 1).

160 "Invader plant" is defined as "...any kind of plant which has under s 2(3) been declared an invader plant, and includes the seed of such plant and any vegetative part of such plant which reproduces itself sexually" (s 1).

161 S 2(3). 
Regulations which list weeds and invader plants and prescribe a range of tools that impose various obligations on "land users" ${ }^{162}$ on whose land these species occur. The 198 listed species are divided into three categories each subject to a different level of regulation. Category I lists plant species that may not be grown anywhere in South Africa, other than "biological control reserves", ${ }^{163}$ and which must be eradicated. ${ }^{164}$ Category II lists plants species which may only be grown with a permit under controlled circumstances. ${ }^{165}$ Category III lists plant species which need not be eradicated but which may not be planted, propagated, imported or traded. ${ }^{166}$ The principal Act prohibits the deliberate or unintentional spread of listed weeds through sale, the transfer of agricultural produce and the movement of livestock. ${ }^{167}$

162 "Land user" is broadly defined as "...the owner of land, and includes: (a) any person who has a personal or real right in respect of any land in his capacity as fiduciary, fidecommissary, servitude holder, possessor, lessee or occupier, irrespective of whether he resides thereon; (b) any person who has the right to cut trees or wood on land or to remove trees, wood or other organic material from land; and (c) in relation to land under the control of a local authority, that local authority, but not a person who carries on prospecting or mining activities" (s 1).

163 The executive officer can designate certain areas as biological control reserves which are primarily reserved for the breeding of biological control agents (Reg 15D).

164 Reg 15A prescribes that these plant species may not occur on any land or inland water surface other than in biological control reserve. The species can only be controlled through the methods prescribed in Reg 15E. In addition, no person may, except for the purposes of biological control undertake the following activities with these plant species: establish, plant, maintain, multiply or propagate plants; import or sell plants or propagating material; and acquire plants or propagating material. The executive officer can, however, grant written exemption on good cause shown.

165 Reg 15B provides that these species can only occur in a demarcated area or biological control reserve. The executive officer is empowered to demarcate these areas and the regulations establish criteria to guide which area can be so declared. Areas for which stream flow reduction license has been granted in terms of $s 36$ of the NWA constitute demarcated areas. No person can sell, acquire or plant or propagating material unless that person is land user in a demarcated area or biological control reserve. A land user can similarly only control these plant species through methods prescribed in Reg $15 \mathrm{E}$ and may not allow them to occur within $30 \mathrm{~m}$ of the 1:50 year flood line of a river, stream, spring, natural channel in which water flows regularly or intermittently, lake, dam or wetland. The executive officer can grant written exemption on good cause shown.

166 Reg $15 \mathrm{C}$ provides that these plant species may similarly only occur in biological control reserves unless the plants were already in existence at the time the CARA Regulations commenced (30 March 2001). No land user shall allow Category III plants to occur within $30 \mathrm{~m}$ of the 1:50 year flood line of a river, stream, spring, natural channel in which water flows regularly or intermittently, lake, dam or wetland and must take all reasonable steps to curtail the spreading of propagating materials. The executive officer can, after consultation with a land user, issue him/her with a directive calling upon him/her to take certain prescribed measures to control or eradicate plants in existence at the date the regulations commenced. In addition, no person may plant, establish, maintain, multiply, propagate, import or sell Category III plants or propagating material unless the executive officer has granted a written exemption on good cause shown.

167 S 5. 
In addition to these restrictions, the CARA Regulations govern the control and eradication of plants which occur contrary to its provisions. ${ }^{168}$ Land users are compelled to select control measures that are appropriate for the species and ecosystem concerned ${ }^{169}$ and these measures must be applied to propagating material and re-growth to prevent listed plant species from forming seed or reestablishing in any manner. ${ }^{170}$ Any action must be undertaken with caution and in manner that will cause the least possible "damage" to the "environment". These two terms are unfortunately not defined and therefore the scope of this provision is plagued with uncertainty. Given that these control measures have the potential to cause greater harm to the environment than the existence of the AIP and fall almost entirely within the discretion of the land user, it would be advisable to provide detailed guidelines regarding what control measure would be "appropriate" in the specific context in any future regulation. ${ }^{171}$

Although imposing a number of obligations on land users, neither CARA nor the CARA Regulations provide that a failure to comply with the above measures constitutes a criminal offence. ${ }^{172}$ However, if these obligations are regarded as control measures, as provided for under CARA, refusal or failure to comply with these obligations constitutes an offence. ${ }^{173}$ In addition, if a direction has been issued to a particular land user to comply with certain control measures, and

168 Reg 15E.

169 The CARA Regulations list a range of control mechanisms from which land users can select which include: uprooting, felling, cutting or burning; treatment with weed killer; biological control; and/or any other method of treatment recognised by the executive officer (Reg 15E(1)).

170 Reg $15 \mathrm{E}(2)$.

171 This guidance is only provided in relation to the use of biological control agents as the CARA Regulations provide that where uncertainty exists regarding the presence or efficacy of these agents, the land user must consult a biological control expert (Reg $15 \mathrm{E}(4))$. Land users appear to have been vested with determining whether this "uncertainty exists" and given the associated costs and time delays incurred in recruiting such an expert, these experts are seldom consulted.

172 Part I of the CARA Regulations is titled "Control measures". AIPs are dealt with in Part II of the CARA Regulations titled "Weed and invader plants". These latter provisions are not defined as controlled measures prescribed under CARA. The CARA Regulations themselves do not contain any offence provisions. It could therefore conceivably be argued that CARA's criminal offence provisions applicable to these control measures do not apply to the provisions in the CARA Regulations dealing it weeds and invader plants.

173 S 6 . The Minister can prescribe control measures relating to a number of issues including the control of weeds and invader plants (s 6(2)(I)). Any land user who refuses or fails to comply with a control measure, is guilty of an offence (s 6(5)). 
the land user fails or refuses to do so, he/she is guilty of an offence. ${ }^{174}$ In order to reduce any potential uncertainty, it would be advisable to clearly define similar obligations relating to weeds and invader species as "control measures" in future legislation.

Despite the commencement of CARA and its regulations over twenty years ago, AIPs continue to ravage South Africa's territory and to date there has not been one successful conviction under this legislation.

There are a number of potential reasons for the above. Perhaps the greatest problem is lack of public awareness regarding the nature and extent of the problem although various organisations, such as Ukuvuka, have implemented nationwide information campaigns. Secondly, CARA is primarily concerned with protecting agricultural production. The Act is administered by officials designated from within the Department of Agriculture whose primary mandate is protecting agricultural production and not issues of biodiversity conservation and water resource management, which are in many cases diametrically opposed to their core function. Closely tied to the above is the failure of CARA to provide any clarity on the roles to be played by the various spheres of government in AIP control. Thirdly, budgetary constraints compel these officials to limit their focus to the agricultural sector. Fourthly, there are many problems with regard to the implementation and enforcement of the CARA Regulations given their adoption of a command and control approach, the scale of the problem, the range of species involved and the need to tailor area-specific control measures. Fifthly, as is mentioned above, the CARA Regulations do not provide adequate guidance regarding what control measures would be appropriate within a given context. Sixthly, the above provisions do not apply to land situated within any area declared to be a mountain catchment area, where crucial regulation is often required. ${ }^{175}$ Finally, the CARA Regulations provide no monitoring requirements and the sanctions imposed by the Act are so minimal

174 S 7. The executive officer can issue a direction order to any land user calling upon him/her to comply with a particular control measure (s 7(1)). Any land user who refuses or fails to comply with a directive, is guilty of an offence (s $7(6))$.

175 S 2(1)(c). 
that they do not constitute a deterrent. ${ }^{176}$ The above aspects have in turn led to the failure of potentially valuable institutions such as conservation committees $^{177}$ and regional conservation committees ${ }^{178}$ to play an active role in the regulation of AIPs at a local and regional level respectively.

\subsubsection{Sustainable Use of Agricultural Resources Draft Bill}

The SUAR Bill has not yet been officially released for public comment ${ }^{179}$ but it will apparently repeal CARA ${ }^{180}$ and limit its regulation of AIPs to those weeds and invader plants which threaten sustainable agriculture. ${ }^{181}$ All other AIPs will be regulated under the Biodiversity Act. The manner in which the provisions in the Biodiversity Act and the SUAR Bill will complement one another with regard to AIP regulation remains to be seen but some degree of overlap appears to be inevitable.

Regulation under the SUAR Bill will take place in a similar manner to that currently adopted under CARA with provision for listing plant species, issuing directives and prescribing control methods. However, it contains two additional provisions of great potential significance to the control of AIP on agricultural land. Firstly, the Minister of Agriculture may be empowered to dispossess owners of degraded land with a view to rehabilitating it after due process has been followed, and on condition that the land user failed to comply with a directive calling upon him/her to do so. ${ }^{182}$ It is, however, unclear what

176 Sanctions for non-compliance with the CARA Regulations are limited to R500 and/or three months imprisonment (s 29(3)).

177 CARA provides for the establishment of conservation committees, comprising of various members including land users in the area concerned, whose primary functions are to promote conservation of natural agricultural resources in an area, advise the Department of Agriculture and exercise powers and duties conferred to it by the Minister (s 15).

178 CARA also provides for the establishment of regional conservation committees which effectively operate as the regional co-ordinators of the local conservation committees (s 16).

179 These comments are therefore based on the Draft 11 produced by the Department of Agriculture on 25 May 2004.

180 S 33.

181 S 15A.

182 S 8. 
procedures must precede such dispossession, the duration of the dispossession and whether any compensation is due in respect of the dispossession and/or the costs of rehabilitation. ${ }^{183}$ Secondly, a prohibition may be imposed on the transfer of agricultural land on which weeds and invader plants are situated unless the Minister of Agriculture is satisfied that a programme is in place to satisfactorily control them. ${ }^{184}$ It is uncertain what the nature of the programme must be, how one goes about getting such a programme approved and what factors the Minister must take into account in deciding whether it is satisfactory or not. Presumably these uncertainties will be clarified by way of regulation. The SUAR Bill is, however, still in draft form and it remains to be seen whether these innovative provisions with withstand public scrutiny.

\subsubsection{Agricultural Pests Act ${ }^{185}$}

The Agricultural Pests Act is also of relevance to AIPs in the context agriculture as it regulates the importation of plants which may undermine agricultural yields. No person may import an alien plant species into South Africa unless they have a permit authorising them to do so. ${ }^{186}$ The Minister of Agriculture has prescribed an array of control measures relating to the destruction, removal, keeping, planting and cultivation of certain alien plants species. ${ }^{187}$ Any person who fails to comply with these control measures may be issued with a compliance order. ${ }^{188}$

183 This provision would have to be read with the property clause contained in the Constitution which provides for mandatory compensation where property is expropriated for a public purpose or in the public interest (s 25).

184 S 22(5).

185 Act 35 of 1983 .

186 S 3(a).

187 These control measures include: Control measures to prevent and combat the spreading of plants, pathogens, insects and exotic animals (GNR 110 of 27 January 2004); Controlled goods in respect of which permits for importation may not be issued (GNR 846 of 12 April 1985); Control measures relating to cotton (GNR 1902 of 12 September 1986); and Imports - Determination of genetically manipulated organisms as controlled goods 188 S 7. (GNR 584 of 22 March 1991). 
Although appearing to prescribe a detailed regime to regulate the importation of potentially invasive plants, these control measures have been largely limited to the regulation of various strains of commercial crops and not the general regulation of AIPs. ${ }^{189}$

\subsubsection{Plant Improvement Act}

The final law of relevance to the regulation of AIPs in the context of agriculture is the Plant Improvement Act. It predominantly regulates the nursery industry through imposing restrictions on the types of plants and plant material that may be subject to import, export, sale and distribution. These activities can only generally be undertaken in respect of plants appearing on the "varietal list", a list produced by the Department of Agriculture, ${ }^{190}$ and they are subject to various registration and other formalities. ${ }^{191}$ Given that AIPs do not appear on the varietal list, the Plant Improvement Act only indirectly contributes to their regulation.

\subsection{Fire risk management}

One may well ask what the relevance of AIPs is to veld fires. Indigenous plants have a very low biomass and have a natural resistance to fire. AIPs, in contrast, have a high biomass which significantly increases the intensity of veld fires. ${ }^{192}$ This added intensity kills indigenous vegetation, increases erosion and stimulates the germination of AIPs seedlings. It is interesting to note that every house burnt down in the devastating fires that swept through Cape Town in 2000 was surrounded by AIPs. ${ }^{193}$ Three laws are of relevance to the regulation

189 These crops include potatoes, cotton, citrus, guavas and wheat strains.

190 S 15.

191 These include: registration of premises (s 7); sale formalities (s 13); registration of new varieties (s16); importation formalities (s 26); and exportation formalities (s 27).

192 These fires can burn with ten times the heat of indigenous plants.

193 See Ukuvuka website at http://www.ukuvuka.org.za. 
of AIPs in the context of fire management, namely: the NV\&FFA; MCAA; and CARA.

\subsubsection{National Veld and Forest Fire Act}

The NV\&FFA is the main law aimed at preventing and combating veld, forest and mountain fires in South Africa. The Act, administered by the DWAF, imposes three main duties on landowners to control veldfires, namely to: prepare and maintain firebreaks; ${ }^{194}$ acquire equipment and have available personnel to fight fires; ${ }^{195}$ and take action to prevent the spread of fires. ${ }^{196}$ Although none of the above provide expressly for the control of AIPs, given their propensity to increase the intensity of veld fires, these obligations are of relevance to owners of land on which these species occur.

In addition, the Act provides for two potentially important planning mechanisms. Firstly, landowners who wish to co-operate in fire prevention, management and control, can form fire protection associations (FPAs). ${ }^{197}$ These FPAs are required to develop and apply a veldfire management strategy for their area ${ }^{198}$ which must include an identification of ecological conditions that affect fire danger, such as that posed by AIP, and how they purport to deal with these risks. ${ }^{199}$ Fifty-four FPAs have been established to date and their fire protection plans increasingly make reference to the need to effectively eradicate AIP in the interest of fire management. ${ }^{200}$

Secondly, the Minister of Water Affairs and Forestry is required to prepare and maintain a fire danger rating system for the entire country on a continuous

$194 \mathrm{~S} 12-16$.

195 S 17.

196 S 18.

197 S 2-8.

198 S $5(1)(a)$.

199 See s 5(1)(d)) and the Fire Protection Association Regulations (GNR 665 of 16 May 2003) which compel FPAs to identify ecological conditions that affect fire danger in their veldfire management strategies and constitutions respectively.

200 Per telecon with Joel Matshate (Assistant Director Forestry Regulations (Veldfires Oversight) DWAF) on 30 January 2006. 
basis. $^{201}$ The aspects which the fire danger rating system must take into account include the type of vegetation in the area ${ }^{202}$ and it can identify dangerous activities and precautionary measures to be adopted to minimise the risk posed by them. ${ }^{203}$ These could feasibly relate to AIPs. This system therefore provides a potentially important planning instrument to identify priority areas for the control of AIPs in the context of fire management. This potential is unrealised as, despite the commencement of the Act six years ago, the Fire Danger Rating System will only come into full operation sometime this year. ${ }^{204}$

\subsubsection{Mountain Catchment Areas Act}

Although predominantly concerned with the conservation of water located in South Africa's water catchments, the MCAA also expressly regulates fire risk management in these areas. The rationale behind the above is that fires can significantly impact on water resources. ${ }^{205}$ Firstly, the Act provides for the establishment of fire protection committees ${ }^{206}$ and the declaration of fire protection plans for catchment management areas. ${ }^{207}$ Owing to the fact that AIPs significantly impact on the risk and intensity of veld fires, these plans, and the associated functions of the fire protection committees, are of potential value to the control and eradication of these species. Provision is also made for rendering financial aid to any fire protection committee and to any owner or

$201 S 9$.

202 S 9(4)(a)(ii).

203 S 9(4)(d).

204 Per telecon with Mr Joel Matshate (DWAF) on 30 January 2006. Although the Fire Danger Rating System was published in GN 1054 of 8 July 2005, it will only come into operation once the necessary computer infrastructure has been put into place. This is expected to be finalised in the first half of 2006.

205 Veldfires can denude these areas of vegetation, thereby increasing soil erosion and the subsequent silting up of water resources situated in these areas.

206 S 7. The role of the fire protection committee is to assist in the implementation of any applicable fire protection plan declared in respect of these areas in terms of $s 8$.

$207 \mathrm{~S} 8$. These fire protection plans provide for the regulation of veld burning; the prevention, control and extinguishing of veld and forest fires; and the functions, powers and duties of the fire protection committee established in respect of the applicable mountain catchment areas. 
occupier of land in respect of expenses incurred by them in compliance with the provisions of any applicable fire protection plan. ${ }^{208}$

None of these provisions has, however, been utilised for various reasons including the existence of overlapping fire management provisions in other legislation and the lack of clarity regarding claims for compensation resulting from fire damage. ${ }^{209}$ This is perhaps a blessing in disguise given that the provisions in the NWA relating to catchment management areas and strategies will effectively supplant the purpose of the MCAA. It is therefore somewhat surprising that the NWA does not repeal the MCAA.

\subsubsection{Conservation of Agricultural Resources Act}

The final law of potential relevance to the regulation of AIPs in the context of fire management is CARA. It empowers the Minister of Agriculture to prescribe control measures relating to the "prevention and control of veld fires". ${ }^{210}$ The Minister has done so in the CARA Regulations and landowners are required to obtain written permission from the executive officer prior to burning any veld situated within a "farm unit". ${ }^{211}$ In addition, the executive officer can issue directions to these landowners when undertaking burns.

The above are of potential relevance to the regulation of AIP as these control measures could relate to the regulation of AIP and fire risks posed by contiguous AIPs may well influence the authorities' decision whether or not to issue any such authorisation. The potential of these provisions to regulate AIPs in relation fire management are undermined by many factors. ${ }^{212}$ In addition, these provisions only apply to "farm units" and unfortunately no guidance is

208 S 10.

209 Rabie and Burgers 1997 SA Public Law 361.

210 S 6(2)(j).

211 Reg 12 in GNR 1048 of 25 May 1984, as amended by GNR 280 of 30 March 2001. "Farm unit" is defined as "... one or more pieces of land, each of which is registered separately in a deeds office, and which is farmed as a single" (Reg 1).

212 See the general criticisms levelled against CARA and the CARA Regulations above in the discussion dealing with regulating AIPs in the context of agricultural conservation. 
provided to executive officers regarding what factors they should take into account when considering permit applications.

\section{In summary - fragmentation, duplication and deficient implementation}

Despite the existence of a comprehensive legislative and administrative framework for regulating AIPs, these species continue to thrive and proliferate. One of the key reasons for this is the adoption of a sectoral approach to regulation with different laws and authorities seeking to control AIPs in one of the following four contexts: biodiversity conservation, water resource management; agricultural resource management; and fire risk management.

The laws relevant to AIP control prescribe many overlapping planning frameworks which guides their implementation in above four contexts. These planning frameworks, and the authorities responsible for developing and implementing them, are summarised in Table 1 below.

TABLE 1

\begin{tabular}{|c|c|c|}
\hline Law & Planning Framework & Overseeing Authority \\
\hline \multicolumn{3}{|c|}{ Framework Provisions } \\
\hline \multirow{2}{*}{ NEMA } & NEMA Principles & All organs of state \\
\hline & EMPs and EIPs & Minister (Enviro) and CEC \\
\hline \multirow{2}{*}{ Property Rates Act } & National Rates Framework & Treasury \\
\hline & Annual Municipal Rates Policy & Municipality \\
\hline $\begin{array}{l}\text { Local Government } \\
\text { Transition Act, Local } \\
\text { Government: } \\
\text { Municipal Structures } \\
\text { Act \& Local } \\
\text { Government: } \\
\text { Municipal Systems } \\
\text { Act }\end{array}$ & Integrated development plans & Municipality \\
\hline $\begin{array}{l}\text { Local Government: } \\
\text { Municipal Systems } \\
\text { Act }\end{array}$ & $\begin{array}{l}\text { Spatial Development } \\
\text { Frameworks }\end{array}$ & Municipality \\
\hline
\end{tabular}




\begin{tabular}{|c|c|c|}
\hline \multicolumn{3}{|c|}{ Biodiversity Conservation } \\
\hline \multirow{5}{*}{ Biodiversity Act } & $\begin{array}{l}\text { National Biodiversity } \\
\text { Framework }\end{array}$ & Minister (Enviro) \\
\hline & Bioregional Plans & Minister (Enviro) or MEC \\
\hline & $\begin{array}{l}\text { Biodiversity Management } \\
\text { Plans }\end{array}$ & $\begin{array}{l}\text { Person, organization or } \\
\text { organ of state }\end{array}$ \\
\hline & $\begin{array}{l}\text { National and Provincial Listing } \\
\text { of Invasive Species }\end{array}$ & Minister (Enviro) or MEC \\
\hline & $\begin{array}{l}\text { Invasive Species Control and } \\
\text { Eradication Strategies }\end{array}$ & $\begin{array}{l}\text { Management Authority } \\
\text { (management plans), } \\
\text { organs of state (EMPs and } \\
\text { EIPs), municipalities (IDP) }\end{array}$ \\
\hline \multirow{2}{*}{ Protected Areas Act } & Declaration of Protected Areas & Minister (Enviro) or MEC \\
\hline & Management Plans & Minister (Enviro) or MEC \\
\hline $\begin{array}{l}\text { Provincial } \\
\text { Legislation }\end{array}$ & Listing of AIPs & $\begin{array}{l}\text { Provincial Conservation } \\
\text { Authority }\end{array}$ \\
\hline \multicolumn{3}{|c|}{ Agricultural Conservation } \\
\hline \multirow{2}{*}{ CARA } & $\begin{array}{l}\text { Listing of Weeds and Invader } \\
\text { Plants }\end{array}$ & Minister (Agriculture) \\
\hline & $\begin{array}{l}\text { Designation of Biological } \\
\text { Control Reserves }\end{array}$ & Executive Officer \\
\hline $\begin{array}{l}\text { Plant Improvement } \\
\text { Act }\end{array}$ & Listing of permitted species & Minister (Agriculture) \\
\hline SUAR Bill & $\begin{array}{l}\text { Listing of Weeds and Invader } \\
\text { Plants }\end{array}$ & Minister (Agriculture) \\
\hline \multicolumn{3}{|l|}{ Water Management } \\
\hline \multirow{4}{*}{ NWA } & $\begin{array}{l}\text { National Water Resource } \\
\text { Strategy }\end{array}$ & $\begin{array}{l}\text { Minister (Water Affairs \& } \\
\text { Forestry) }\end{array}$ \\
\hline & $\begin{array}{l}\text { Catchment Management } \\
\text { Strategies }\end{array}$ & $\begin{array}{l}\text { Catchment Management } \\
\text { Agency }\end{array}$ \\
\hline & Resource Quality Objectives & $\begin{array}{l}\text { Minister (Water Affairs \& } \\
\text { Forestry) }\end{array}$ \\
\hline & Reserve Determination & $\begin{array}{l}\text { Minister (Water Affairs \& } \\
\text { Forestry) }\end{array}$ \\
\hline MCAA & $\begin{array}{l}\text { Declarations of Mountain } \\
\text { Catchment Areas }\end{array}$ & $\begin{array}{l}\text { Provincial Conservation } \\
\text { Authority }\end{array}$ \\
\hline $\begin{array}{l}\text { Provincial } \\
\text { Legislation }\end{array}$ & $\begin{array}{l}\text { Listing of "noxious aquatic } \\
\text { growths" }\end{array}$ & $\begin{array}{l}\text { Provincial Conservation } \\
\text { Authority }\end{array}$ \\
\hline \multicolumn{3}{|l|}{ Fire Management } \\
\hline \multirow{2}{*}{$N V \& F F A$} & $\begin{array}{l}\text { Veldfire Management } \\
\text { Strategies }\end{array}$ & Fire Protection Association \\
\hline & Fire Danger Rating System & $\begin{array}{l}\text { Minister (Water Affairs \& } \\
\text { Forestry) }\end{array}$ \\
\hline MCAA & $\begin{array}{l}\text { Fire Protection Committees } \\
\text { and Plans }\end{array}$ & $\begin{array}{l}\text { Provincial Conservation } \\
\text { Authority }\end{array}$ \\
\hline
\end{tabular}

National laws currently provide for a range of legislative tools to regulate AIPS such as: environmental impact assessment; permitting; prohibitions; duty of 
care obligations; directives; reporting; regulating control methods; dispossessing land for the purposes of rehabilitation; restricting the transfer of land that is subject to invasion; and providing limited financial assistance and incentives. The range of tools and authorities responsible for their administration are summarised in the Table 2 below.

TABLE 2

\begin{tabular}{|c|c|c|}
\hline Law & Tool & Overseeing Authority \\
\hline \multicolumn{3}{|c|}{ Framework Provisions } \\
\hline \multirow{2}{*}{ NEMA } & EIA & DEAT and Provincial HOD \\
\hline & Duty of Care & DEAT and Provincial HOD \\
\hline \multirow[b]{2}{*}{$E C A$} & EIA & DEAT and Provincial HOD \\
\hline & Duty of Care & $\begin{array}{l}\text { Minister (Enviro), Provincial } \\
\text { HOD, local authority or } \\
\text { government institution }\end{array}$ \\
\hline \multicolumn{3}{|c|}{ Biodiversity Conservation } \\
\hline \multirow{6}{*}{ Biodiversity Act } & $\begin{array}{l}\text { Permitting for restricted } \\
\text { activities }\end{array}$ & Issuing authority \\
\hline & EIA & Issuing Authority \\
\hline & Prohibited activities & Minister (Enviro) \\
\hline & Duty of Care & Competent Authority \\
\hline & Invasive Species Reports & Management Authority \\
\hline & $\begin{array}{l}\text { Control methods for Invasive } \\
\text { Species }\end{array}$ & DEAT \\
\hline $\begin{array}{l}\text { Protected Areas } \\
\text { Act }\end{array}$ & Declaration of Protected Areas & Minister (Enviro) or MEC \\
\hline \multicolumn{3}{|c|}{ Agricultural Conservation } \\
\hline \multirow[t]{3}{*}{ CARA } & $\begin{array}{l}\text { Restriction on activities } \\
\text { relating to listed weeds and } \\
\text { invader plants }\end{array}$ & Executive Officer \\
\hline & Control measures & Executive Officer \\
\hline & Directions & Executive Officer \\
\hline \multirow{2}{*}{$\begin{array}{l}\text { Agricultural Pests } \\
\text { Act }\end{array}$} & Permitting for imports & Minister (Agriculture) \\
\hline & Control measures & Minister (Agriculture) \\
\hline $\begin{array}{l}\text { Plant } \\
\text { Improvement Act }\end{array}$ & General Regulation & Minister (Agriculture) \\
\hline \multirow{4}{*}{ SUAR Bill } & $\begin{array}{l}\text { Restriction on activities } \\
\text { relating to listed weeds and } \\
\text { invader plants }\end{array}$ & Executive Officer \\
\hline & Directives & Executive Officer \\
\hline & $\begin{array}{l}\text { Dispossession for } \\
\text { rehabilitation }\end{array}$ & Minister (Agriculture) \\
\hline & Prohibition on transfer & Minister (Agriculture) \\
\hline
\end{tabular}




\begin{tabular}{|l|l|l|}
\hline Water Management & \multicolumn{2}{|l|}{} \\
\hline \multirow{4}{*}{ NWA } & Duty of Care & $\begin{array}{l}\text { Catchment Management } \\
\text { Agency }\end{array}$ \\
\cline { 2 - 3 } & Regulation of Water Use & Responsible Authority \\
\hline \multirow{4}{*}{ FCAA } & Directions & $\begin{array}{l}\text { Provincial Conservation } \\
\text { Authority }\end{array}$ \\
\cline { 2 - 3 } & Financial Incentives & $\begin{array}{l}\text { Minister (Water Affairs \& } \\
\text { Forestry) }\end{array}$ \\
\hline \multirow{3}{*}{ NV\&FFA } & \multicolumn{2}{|l}{} \\
\hline \multirow{3}{*}{ CARA } & Maintain firebreaks & DWAF \\
\cline { 2 - 3 } & Measures to fight fires & DWAF \\
\cline { 2 - 3 } & Measures to prevent spread & DWAF \\
\hline \multirow{3}{*}{ MCAA } & Control Measures & $\begin{array}{l}\text { Minister (Water Affairs and } \\
\text { Forestry) or Executive officer }\end{array}$ \\
\cline { 2 - 3 } & Directions & Executive officer \\
\hline & Directions & $\begin{array}{l}\text { Provincial Conservation } \\
\text { Authority }\end{array}$ \\
\cline { 2 - 3 } & Financial Assistance & $\begin{array}{l}\text { Provincial Conservation } \\
\text { Authority \& Minister (Finance) }\end{array}$ \\
\hline
\end{tabular}

What is evident from the above is that there is, as with the planning frameworks, a radical duplication in these tools and the authorities responsible for their implementation.

This fragmented approach is inappropriate given that the control of AIPs for one purpose will frequently simultaneously achieve other desired purposes ${ }^{213}$ and has resulted in an uncoordinated regulatory regime prescribing overlapping planning frameworks, legal tools and administrative responsibilities. This fragmentation and duplication places untenable burdens on state resources with the resultant disuse of many of the legislative tools.

Given the nature of the problem and current capacity constraints, it would be preferable for the government to adopt a more integrated approach to AIP regulation. Three questions arise when considering the way forward and how to achieve this integration. Firstly, how can one rationalise the planning frameworks prescribed in these laws? Secondly, how can one rationalise and

213 The removal of AIPs to form a firebreak, for example, may simultaneously increase available surface and groundwater and ensure the protection of indigenous species in the area. 
improve the numerous legislative tools providing for AIPs control? Finally, who should be responsible for implementing these laws?

\section{$4 \quad$ The way forward}

\subsection{Reconciling planning}

The value and necessity of providing a comprehensive planning framework in any regulatory context is not subject to debate. However, as is evident from Table 1, there is a significant degree of overlap between the planning instruments relevant to AIP regulation. This replication potentially undermines the value of the individual planning instruments and unnecessarily duplicates the functions of different authorities. There is, however, an increasing tendency in recent sectoral legislation to recognise the importance of co-ordination and many of these laws expressly provide that their planning frameworks must be aligned with those prescribed under other relevant legislation. ${ }^{214}$ These attempts at co-ordination are unfortunately rather fragmented, predominantly limited to the context of biodiversity conservation and generally prescribe no mechanisms or institutions to aid this integration. ${ }^{215}$ The prescription of a national alien invasive strategy, with which all relevant institutions planning

214 Examples include the following. The Biodiversity Act provides that the national biodiversity framework, bioregional plans and biodiversity management plans must not conflict with: all relevant EMPs and EIPs prepared in terms of NEMA; IDPs adopted by municipalities in terms of the Local Government: Municipal Systems Act and any other relevant spatial development frameworks; and any other plans prepared in terms of national or provincial legislation that are relevant (s 48). Biodiversity management plans must also be consistent with existing IDPs (s 45(c)(vi). Various institutions, such as management authorities and municipalities, are required to prepare and incorporate invasive species control and eradication species in a range of planning mechanisms prescribed under other legislation (s 76 and s 77). The NWA provides that catchment management strategies must take into account any relevant national or regional plans prepared in terms of any other law (s 9(f). The NWA provides that the NWRS must determine the inter-relationship between institutions involved in water resource management and promote the management of catchments within a water management area in a holistic and integrated manner (s 6(k) and (I)). The Protected Areas Act provides that management plans must take into account any applicable aspects of the integrated development plan of the municipality in which the protected areas is situated (s 39(4)).

215 An exception in this regard is the Biodiversity Act which provides for the establishment of an entity to assist the Minister of Environmental Affairs in co-ordinating programmes for the prevention, control and eradication of invasive species. This entity could play a vital role in facilitating this co-ordination and alignment (s 75(5)). 
instruments must comply and subject to mandatory reporting requirements, provides a potential mechanism for facilitating the necessary alignment.

NEMA provides further valuable mechanisms for ensuring co-operative environmental governance but these have disappointingly not been effectively utilised to achieve co-ordination in the context of AIP regulation. Every authority involved in developing and administering the above planning frameworks is required to prepare EMP or EIPs. Given that the main purpose of these EMPs and EIPs is to increase co-operative environmental governance, it is disappointing that none of the current versions of the EMPs and EIPs prepared by authorities have achieved this in respect of AIP regulation. Fortunately these EMPs and EIPs have to be reviewed every four years and this provides an important opportunity for the CEC, mandated to evaluate these plans prior to approval, to ensure that these authorities do so in their subsequent plans. This could go a long way towards co-ordinating the functions of these authorities.

The alignment could also be accelerated by repealing or rationalizing current planning instruments which create unnecessary duplication or have fallen into disuse. A prime example is the MCAA which makes provision for the establishment of fire protection committees and fire protection plans. These provisions have not been used to date and the entire purpose of the Act is adequately regulated under subsequent legislation governing fire management, ${ }^{216}$ water management ${ }^{217}$ and biodiversity conservation. ${ }^{218}$ The repeal of the MCAA would therefore not appear to undermine any of the rationale for which it was originally enacted. In addition, the ambit of the NV\&FFA should be limited to fire response and not be extended to AIP control

216 The NV\&FFA effectively duplicates the provisions of the MCAA in that it too provides for veldfire associations and veldfire management strategies as opposed to fire protection plans and fire protection committees.

217 The NWA similarly duplicates the provisions of the MCAA in that it provides for the designation of catchment management areas which shall be regulated for the same purposes as mountain catchment areas.

218 To the extent that the MCAA provided subsidiary assistance to biodiversity conservation, it has become superfluous given the comprehensive regime prescribed under the Biodiversity Act. 
given that the latter function is adequately regulated under contemporary legislation. ${ }^{219}$

The provision for listing AIPs under CARA, the Biodiversity Act, Plant Improvement Act and provincial legislation also creates unnecessary duplication. It would be preferable to have a single listing system which can differentiate between areas and species. It would also be desirable to adopt the listing approach prescribed under the Biodiversity Act for many reasons. Firstly, the Act will be administered by South Africa's lead environmental agency as opposed to agricultural authorities which may have conflicting agendas and capacity constraints. Secondly, the Act provides for broad powers of delegation which should allow the administration to be undertaken by the most appropriate authority. Thirdly, the Act allows for differential regulation between areas and species. This flexibility is essential in the context of AIP regulation given the numerous variables which need to be considered to ensure effective control. Fourthly, the Act provides for a broad range of control measures to complement the listing system. Finally, provision is made for mandatory cross-departmental consultation which should ensure that all relevant departmental interests are considered prior to these measures being implemented under the Act. ${ }^{220}$ An alternative approach would be to reform all existing lists of relevance to AIP regulation to minimise legislative and administrative duplication.

\subsection{Reconciling implementation}

Although the rationalisation of the planning frameworks should filter down to the implementation of the specific tools and the government's current legislative reform process will ensure that certain of the laws will fall by the wayside, ${ }^{221}$

219 These laws include: NEMA; Biodiversity Act; NWA; Protected Areas Act; and CARA.

220 S 79 read with s 99.

221 The EIA Regulations promulgated under the ECA will be repealed when NEMA's new EIA framework comes into force. The SUAR Bill will similarly repeal CARA when it is enacted into law. 
there appear to be a number of ways in which these tools themselves could be further rationalised without prejudicing the overall goal of AIP regulation.

Firstly, as was argued above in relation to the planning frameworks, AIPs should be removed from the realm of agricultural and provincial legislation as they are more than adequately dealt with under contemporary national environmental legislation. ${ }^{222}$ However, the novel provisions contained in the SUAR Bill relating to restricting the transferability of land subject to significant invasion and the confiscation of property for the purpose of rehabilitation should be incorporated under the Alien Invasive Regulations currently being drafted under the Biodiversity Act. These provisions could be extended to preclude the issuing of various environmental and planning authorisations ${ }^{223}$ until such time as the land in question has been cleared to the satisfaction of the relevant authorities. Secondly, the need to prescribe additional duty of care provisions under the Biodiversity Act relating specifically to AIPs is debatable given that the almost identical provisions in NEMA and the NWA are more than broadly enough framed to cover AIPs. Perhaps it is nonetheless valuable given the diverse threats posed by these species. However, the content of the Biodiversity Act's duty of care provisions must be significantly fleshed out by way of regulation so as to ensure their practicability and distinctiveness. Thirdly, it would be ill-advised to prescribe a separate EIA framework to specifically regulate AIPs under the Biodiversity Act given the absurd fragmentation already plaguing South Africa's EIA regime. Any EIA process should be aligned with that to be shortly prescribed under NEMA. This would avoid unnecessary duplication with the resultant resource burdens placed on implementing authorities. Fourthly, the MCAA and AIP provisions housed in provincial legislation should be repealed as they are largely superfluous for the reasons discussed above in the context of planning.

222 CARA's provisions relating specifically to the control of AIPs (listing AIPs, prohibited activities, control measures and directives) are largely duplicated in NEMA and the Biodiversity Act. CARA's provisions relating to AIPs in the context of fire management (control measures and directives) are similarly largely duplicated in the NV\&FFA.

223 These authorisations could include: planning permission under provincial planning legislation; prospecting and mining licences under the Mineral and Petroleum Resources Development Act; "EIA authorisations" under the ECA; water licences under the NWA; and "ploughing permits" under CARA. 
An additional concern common to the majority of legislative tools of relevance to AIP control in South Africa is that they almost exclusively rely on a command and control approach to regulation. Although command and control measures will always be needed, international experience has shown that these measures alone are inadequate to regulate AIPs where: the origins of invasion are diffuse; solutions complex; and implementation and enforcement difficult as a result of a proliferation of fragmented laws and jurisdictional and institutional competencies. ${ }^{224}$ The limitations of this approach and the need for it to be supplemented or even replaced by an incentive based approach, has been identified in various international conventions and domestic policy documents such as the Convention on Biological Diversity ${ }^{225}$ and the White Paper on Biodiversity. 226

There are two main opportunities for implementing incentives in the context of AIP regulation namely: offering landowners property tax rebates if their land is cleared of AIPs; and allowing various landowners and institutions to deduct their costs incurred in clearing AIPs for income tax purposes. ${ }^{227}$ The introduction of incentives is essential in the context of AIP owing to: the frightening estimated expenditure necessary to control AIPs over the next

224 Glowka "Accountability and Legislation" 68.

225 A 11 provides that signatory parties must "...as far as possible and as appropriate, adopt economically and socially sound measures that act as incentives for the conservation and sustainable use of components of biological diversity". South Africa ratified the Convention in November 1995.

226 One of its main six goals of the White Paper on Biodiversity $(\mathrm{n} 6)$ is to "...create conditions and incentives that support the conservation and sustainable use of biodiversity" (ch 3(D)). The White Paper on Biodiversity recognises that although South Africa has a substantial amount of legislation governing the use and conservation of natural resources, the "command and control" approach adopted by these laws is inadequate to address the underlying causes of biodiversity loss (ch 3 , goal 5.2 at 81). The government further acknowledges that it lacks the financial resources to invest in conserving biodiversity and that "...the introduction of incentives by the government is an important way in which people can be motivated to conserve and use biodiversity sustainably" (see generally ch 3 , goal 5 at 81-83). In this regard, the White Paper on Biodiversity proposes a number of potential areas that need to be addressed including that the government must provide incentives to landowners to control and eradicate alien organisms identified as threatening biodiversity (ch 2, goal 1.6 at 38).

227 See generally Paterson 2005 SALJ 182. 
twenty years; the capacity and resource constraints afflicting South Africa's conservation authorities; and the failure of current approaches to regulate AIPs.

\subsection{Reconciling Administration}

The final question to address is which, or what combination, of the four national authorities, ${ }^{228}$ nine provincial authorities ${ }^{229}$ and numerous local and statutory authorities $^{230}$ currently involved in some aspect of AIP regulation, should be responsible for implementing and administering the above tools? As has been mentioned above, many of their tasks are duplicated and/or overlap with one another.

The rationalisation proposals discussed above in relation to planning and implementation should go a long way towards limiting this administrative duplication. These include the repeal of the MCAA and the removal of AIP regulation from the scope of CARA and provincial legislation. This seems reasonable given that the provisions contained in the former are outdated and the latter superfluous for the reasons stated above. In addition, the track record of the Department of Agriculture in achieving the holistic regulation of AIPs in the past two decades is debatable.

This would effectively leave the bulk of planning administration to two national departments, namely DEAT and DWAF. These Departments have a historically close working relationship, are the lead agencies in environmental protection and are responsible for administering the bulk of the remaining legislation of relevance to AIP regulation. Co-ordinating the planning efforts of two national

228 These are DEAT, DWAF, Department of Agriculture and the Department of Provincial and Local Government.

229 These are the nine provincial departments responsible for environmental affairs.

230 These include South African National Parks, provincial conservation authorities, management authorities appointed under the Protected Areas Act, catchment management agencies, fire protection associations incorporated under the NV\&FFA and executive officers appointed under CARA. 
departments should be far easier than three, especially where the third, the Department of Agriculture, has potentially conflicting agendas.

With regard to implementing the various tools aimed at regulating AIPs, it appears preferable for these national departments to delegate their functions to provincial authorities, local authorities or catchment management agencies as these institutions often have a far clearer understanding of the challenges posed by AIP within their jurisdictional boundaries. An exception could be introduced in the case of protected areas where these functions should be delegated to the duly appointed management authorities. They are specifically appointed to manage these protected areas and to limit their power to regulate AIPs situated within their respective boundaries would appear absurd. However, these management authorities must ensure that their activities in relation to AIPs are coordinated with the range of authorities responsible for managing these species in adjacent areas. This could be achieved through providing for cross-representation on the various relevant institutions such as catchment management agencies, fire protection associations and management authorities. This should minimise any potential duplication in these institutions functions and facilitate co-ordination.

However, given the broad range of tools and authorities involved, there will always be some level of overlap and it is therefore imperative that clear mechanisms are prescribed to facilitate co-ordination. The government has fortunately introduced a range of these mechanisms in recent laws such as integrated permitting arrangements, ${ }^{231}$ mandatory cross-departmental and cross-institutional consultation and the potential establishment of an institution for the specific purpose of co-ordinating and implementing programmes for the prevention, control or eradication of invasive species. ${ }^{232}$ The above must be seen within the broader context of the constitutional imperative to achieve cooperative governance which should ensure that some level of co-ordination is integrated into the relevant planning frameworks and informs the 
implementation and administration of the various tools specifically aimed at achieving AIP regulation.

\section{Conclusion}

South Africa has a comprehensive legislative regime for AIP regulation. However, as should be evident from the above analysis, the current regime reflects many of the weaknesses identified by the World Conservation Union ${ }^{233}$ as common to domestic AIP regimes, particularly: fragmented legal and institutional frameworks; ${ }^{234}$ and problems relating to compliance, enforcement and available remedies. ${ }^{235}$ These weaknesses have led to the rather "...messy, frustrating, depressing, and unpredictable..." ${ }^{236}$ regulation of AIPs over the past twenty years.

Although NEMA, the NWA, Biodiversity Act and Protected Areas Act do provide some solutions to overcome these weaknesses, further rationalisation and integration along the lines proposed in this article are required in order to heed the government's call to develop

.... a coherent legislative framework [...] streamlined along the lines of the principles endorsed by the Convention on Biological Diversity.

These principles include: adopting a cross sectoral ecosystem approach to management; promoting the use of incentives; decentralising management to the lowest possible level; involving all relevant sectors; making provision for

233 Shine, Williams and Gündling Designing Legal and Institutional Frameworks 37-38.

234 Problems regarding fragmentation include: absence of a broad planning frameworks; lack of institutional and legal co-ordination; and the centralisation of administration.

235 Problems relating to compliance, enforcement include: reliance on a command and control approach; lack of measures to address vectors of unintentional introductions; cumbersome, time consuming and costly risk assessment and permit procedures; lack of mandatory monitoring; lack of clearly defined powers and obligations for eradication, containment, control; and an enforcement deficit (low levels of compliance and poor accountability) because conventional criminal and civil law procedures are difficult to apply in the alien context.

236 Bright Life Out of Bounds 2. 
EIA; advocating a precautionary approach to management; implementing the polluter pays principle; and promoting public awareness and training.

The challenge is immense given the range of issues involved, the array of laws currently providing for AIP regulation and the variety of authorities responsible for their administration. However, with every waking moment the invasion, with its myriad of associated socio-economic and environmental consequences, progresses and clearing a path towards effective alien invasive control becomes more imperative. 


\section{Bibliography}

Bright Life Out of Bounds

Bright C Life Out of Bounds: Bioinvasion in a Borderless World (World Watch Institute 1998)

Department of Agriculture Environmental Implementation Plan 2002

Department of Agriculture Environmental Implementation Plan (First

Edition) 2002 (GN 659 Government Gazette 23374 of 17 May 2002)

Davies and Day Vanishing Waters

Davies B and Day J Vanishing Waters (UCT Press Cape Town 1998)

DEAT Combined Environmental Implementation and Environmental Management Plan 2002

Department of Environmental Affairs and Tourism Combined Environmental Implementation and Environmental Management Plan (First Edition) 2002 (GN 354 Government Gazette 23232 of 28 March 2002)

DEAT Environmental Impacts of Invading Alien Plants 2002

Department of Environmental Affairs and Tourism The Environmental Impacts of Invading Alien Plants in South Africa 2002 (Government Printers)

DEAT State of the Environment Report 1999

Department of Environmental Affairs and Tourism State of the Environment Report 1999 (Government Printers)

DEAT White Paper on the Conservation and Use of South Africa's Biodiversity 1997

Department of Environmental Affairs and Tourism White Paper on the Conservation and Use of South Africa's Biodiversity 1997 (GN 1095 Government Gazette 18163 dated 28 July 1997) 
DWAF Combined Environmental Implementation and Environmental Management Plan 2001

Department of Water Affairs and Forestry Combined Environmental Implementation and Environmental Management Plan (First Edition) 2001 (GN 1357 Government Gazette 22929 of 14 December 2001)

DWAF National Water Resources Strategy 2004

Department of Water Affairs and Forestry National Water Resources Strategy (First Edition) 2004 (Government Printers)

Didiza "Invasive Species"

Didiza T "An Agricultural Perspective on Invasive Species" in Best Management Practices for Preventing and Controlling Alien Species: Symposium Proceedings Kirstenbosch Cape Town 22-24 February 20005

Glowka "Accountability and Legislation"

Glowka L "Accountability and Legislation” in Best Management Practices for Preventing and Controlling Alien Species: Symposium Proceedings Kirstenbosch Cape Town 22-24 February 200068

La Maitre et al 2002 Forest Ecology and Management La Maitre DC et al "Invasive alien trees and water resources in South Africa: case studies of the costs and benefits of management" 2002 (160) Forest Ecology and Management 143

Moosa "Invasive Aliens/Aquatic Invaders" Moosa V "An Environmental Perspective on Invasive Aliens/Aquatic Invaders" in Best Management Practices for Preventing and Controlling Alien Species: Symposium Proceedings Working for Water Programme 20008

Paterson 2005 SALJ

Paterson A "Tax Incentives: A Novel Approach to Biodiversity Conservation in South Africa" 2005 (1) SALJ 182 
Preston and Siegfried 1995 South African Journal of Wildlife Research

Preston GR and Siegfried WR "The protection of biological diversity in South Africa: Profiles and perceptions of professional practitioners in nature conservation agencies and natural history museums" 1995 (25) South African Journal of Wildlife Research 49

Rabie and Burgers 1997 SA Public Law Rabie A and Burgers C "The Mountain Catchment Areas Act and its Implementation" 1997 (12) SA Public Law 357

Richardson and Van Wilgen 2004 South African Journal of Science Richardson D and Van Wilgen B "Invasive alien plants in South Africa: How well do we understand the ecological impacts?" 2004 (100) South African Journal of Science 45

Shine et al Designing Legal and Institutional Frameworks Shine C, Williams N and Gündling L A Guide to Designing Legal and Institutional Frameworks on Alien Invasive Species 2002 (Environmental Policy and Law Paper No 40 World Conservation Union Environmental Law Centre)

Soltau 1999 SAJELP

Soltau F "The National Environmental Management Act and Liability for Environmental Damage" 1999 (6) SAJELP 43

Turpie 2004 South African Journal of Science

Turpie $\mathrm{J}$ "The role of resource economics in the control of invasive alien plants in South Africa" 2004 (100) South African Journal of Science 87

WfW Annual Report 2003/2004

Working for Water Programme Working For Water Annual Report 2003/2004 (Government Printers)

WCMC Global Biodiversity Status

World Conservation Monitoring Centre Global Biodiversity Status of the Earth's Living Resources (Chapman and Hall London 1992) 
Whittenberg and Cock (eds) Invasive Alien Species

Whittenberg R and Cock M (Eds) Invasive Alien Species: A Toolkit of Best

Prevention and Management Practices (Global Invasive Species

Programme CAB International Oxon 2001)

Wynberg 2002 South African Journal of Science

Wynberg $R$ "A decade of biodiversity conservation and use in South Africa:

tracking progress from Rio Earth Summit to the Johannesburg World

Summit on Sustainable Development" 2002 (98) South African Journal of

Science 233

\section{Register of legislation}

Agricultural Pests Act 35 of 1983

Animal Improvement Act 62 of 1998

Conservation of Agricultural Resources Act 43 of 1983

Constitution of the Republic of South Africa 1996

Environment Conservation Act 73 of 1989

Forest Act 122 of 1984

Gauteng Nature Conservation Ordinance 12 of 1983

Genetically Modified Organisms Act 15 of 1997

GNR 110 Government Gazette 9047 of 27 January 1984

GNR 1048 Government Gazette 10029 of 25 May 1984

GNR 846 Government Gazette 9693 of 12 April 1985

GNR 1902 Government Gazette 10431 of 12 September 1986

GNR 584 Government Gazette 13077 of 22 March 1991

GNR 1182 Government Gazette 18261 of 5 September 1997

GNR 1183 Government Gazette 18261 of 5 September 1997

GNR 1184 Government Gazette 18261 of 5 September 1997

GNR 280 Government Gazette 22166 of 30 March 2001

GNR 796 Government Gazette 22605 of 24 August 2001

GNR 665 Government Gazette 24870 of 16 May 2003

Lake Areas Development Act 39 of 1975

Local Government: Municipal Property Rates Act 6 of 2004 
Local Government: Municipal Structures Act 117 of 1998

Local Government: Municipal Systems Act 32 of 2000

Local Government Transition Act 209 of 1993

Marine Living Resources Act 18 of 1998

Mpumalanga Nature Conservation Act 10 of 1998

Mountain Catchment Areas Act 63 of 1970

National Environmental Management Act 107 of 1998

National Environmental Management Amendment Act 8 of 2004

National Environmental Management: Biodiversity Act 10 of 2004

National Environmental Management: Protected Areas Act 57 of 2003

National Environmental Management: Protected Areas Amendment Act 31 of 2004

National Forests Act 84 of 1998

National Heritage Resources Act 25 of 1999

National Parks Act 57 of 1976

National Water Act 36 of 1998

National Veld and Forest Fire Act 101 of 1998

Plant Breeders' Rights Act 15 of 1976

Plant Improvement Act 53 of 1976

World Heritage Convention Act 49 of 1999

Western Cape Nature Conservation Laws Amendment Act 2000

\section{Register of cases}

Hichange Investments (Pty) Ltd v Cape Produce Co (Pty) Ltd t/a Pelts Products 20041 All SA 655

\section{Treaties and other international sources}

Convention on Biological Diversity (31) ILM 818

Convention on Wetlands of International Importance especially as Waterfowl Habitat (11) ILM 969

Revised SADC Protocol on Shared Watercourse Systems (40) ILM 321 


\section{Register of Internet resources}

DWAF http://www.dwaf.gov.za/Documents/ $15 \mathrm{Apr}$

Department of Water Affairs and Forestry 2005 Portfolio Committee

Presentation on Water Affairs and Forestry on 22 June 2005 [Found on

Internet] http://www.dwaf.gov.za/Documents/ [Date of use 14 Apr 2006]

DWAF http://www.dwaf.gov.za/wfw/ $15 \mathrm{Apr}$

Department of Water Affairs and Forestry 2001 Work for Water Programme

[Found on Internet] http://www.dwaf.gov.za/wfw/ [Date of use 15 April 2006]

IUCN http://www.iucn.org/ $15 \mathrm{Apr}$

International Union for the Conservation of Nature and Natural Resources 2006 World Conservation Union http://www.iucn.org/ [Date of use 15 April 2006]

Ukuvuka http://www.ukuvuka.org.za/ $15 \mathrm{Apr}$

Uvuvuka Campaign 2003 Reducing the Risk of Fire [Found on Internet] http://www.ukuvuka.org.za/ [Date of use 15 April 2006]

UNEP http://www.unep.org 15 Apr

United Nations Environment Programme 2006 Environment for

Development [Found on Internet] http://www.unep.org/ [Date of use 15 April 2006]

UNEP http://www.unep.org 15 Apr

United Nations Environment Programme 1985 Protocol Concerning

Protected Areas and Wild Fauna and Flora in the Eastern African Region

[Found on Internet] http://www.unep.org [Date of use 15 April 2006]

WCPA http://www.iucn.org/themes/wcpa/wpc2003/pdfs/outputs/africa/ $15 \mathrm{Apr}$ World Commission on Protected Areas 2003 Revised African Convention on the Conservation of Nature and Natural Resources [Found on Internet] 
http://www.iucn.org/themes/wcpa/wpc2003/pdfs/outputs/africa/ [Date of use 15 April 2006]

WoF http://www.fire.uni-freiburg.de/WoF/ $15 \mathrm{Apr}$

Working on Fire Campaign 2006 Integrated Fire Management

in Eight Pilot Umbrella Fire Protection Associations in South Africa [Found on Internet] http://www.fire.uni-freiburg.de/WoF/ [Date of use 15 April 2006] 